\title{
A dynamic climate and ecosystem state during the Paleocene-Eocene Thermal Maximum: inferences from dinoflagellate cyst assemblages on the New Jersey Shelf
}

\author{
A. Sluijs* and H. Brinkhuis \\ Palaeoecology, Institute of Environmental Biology, Utrecht University, Laboratory of Palaeobotany and Palynology, \\ Budapestlaan 4, 3584 CD Utrecht, The Netherlands \\ * Invited contribution by A. Sluijs, recipient of the EGU Outstanding Young Scientist Award 2007.
}

Received: 15 April 2009 - Published in Biogeosciences Discuss.: 20 May 2009

Revised: 13 August 2009 - Accepted: 14 August 2009 - Published: 25 August 2009

\begin{abstract}
Late Paleocene and Early Eocene climates and ecosystems underwent significant change during several transient global warming phases, associated with rapidly increasing atmospheric carbon concentrations, of which the Paleocene-Eocene Thermal Maximum (PETM; 55.5 Ma) is best studied. While biotic response to the PETM as a whole ( $\sim 170$ kyrs) has been relatively well documented, variations during the PETM have been neglected. Here we present organic dinoflagellate cyst (dinocyst) distribution patterns across two stratigraphically expanded PETM sections from the New Jersey Shelf, Bass River and Wilson Lake. Many previously studied sites show a uniform abundance of the thermophilic and presumably heterotrophic taxon Apectodinium that spans the entire carbon isotope excursion (CIE) of the PETM. In contrast, the New Jersey sections show large variations in abundances of many taxa during the PETM, including the new species Florentinia reichartii that we formally propose. We infer paleoecological preferences of taxa that show temporal abundance peaks, both qualitative and absolute quantitative, from empirical as well as statistical information, i.e., principle (PCA) and canonical correspondence analyses (CCA). In the CCAs, we combine the dinocyst data with previously published environmental proxy data from these locations, such as TEX 86 paleothermometry, magnetic susceptibility and sedimentary size fraction. The combined information supports previous inferences that sea level rose during the PETM, but also indicates a (regional) increase in
\end{abstract}

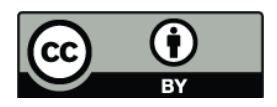

Correspondence to: A. Sluijs (a.sluijs@uu.nl) fresh-water runoff that started $\sim 10 \mathrm{kyr}$ after the onset of the $\mathrm{CIE}$, and perhaps precession-paced cycles in sea surface productivity. The highly variable dinocyst assemblages of the PETM contrast with rather stable Upper Paleocene assemblages, which suggests that carbon input caused a dynamic climate state, at least regionally.

\section{Introduction}

Now that almost everyone expects a certain amount of global warming by the end of the century (IPCC, 2007), interest to climate change as a whole is increasing. Global and regional climate models expect an increase in year-to-year variability of weather resulting from increasing $\mathrm{CO}_{2}$ concentrations (e.g., Diffenbaugh et al., 2008). If so, one may expect increasing variability in climate over the coming centuries, millennia and even longer time scales, because carbon concentrations in the atmosphere are expected to remain high for several hundreds of thousands of years (Archer, 2005; Archer et al., 2009). One way to assess climate dynamics in a rapidly warming world is to perform high-resolution paleoenvironmental reconstructions on high-accumulation rate sediment sections deposited during a past analogue, such as the Paleocene-Eocene Thermal Maximum (PETM).

The PETM represents a $\sim 170 \mathrm{kyr}$ (Röhl et al., 2007; Abdul Aziz et al., 2008) long episode of extreme global greenhouse warmth $\sim 55.5$ Million years ago (Ma), superimposed on the already warm Late Paleocene and Early Eocene (Bowen et al., 2006; Sluijs et al., 2007a). The onset of the PETM is marked by a pronounced negative stable carbon

Published by Copernicus Publications on behalf of the European Geosciences Union. 
isotope $\left(\delta^{13} \mathrm{C}\right)$ excursion (CIE), documented in marine and terrestrial sedimentary components (Kennett and Stott, 1991; Koch et al., 1992; Schouten et al., 2007) and an additional global warming of $\sim 5-9^{\circ} \mathrm{C}$ (Kennett and Stott, 1991; Zachos et al., 2003; Sluijs et al., 2006). The CIE is widely taken to evidence the injection of large amounts of ${ }^{13} \mathrm{C}$ depleted carbon in the shape of $\mathrm{CH}_{4}$ and/or $\mathrm{CO}_{2}$ into the ocean-atmosphere system (Dickens et al., 1995, 1997). This addition of 'light' carbon is generally thought to lie at the root of this episode of extreme global warmth (Higgins and Schrag, 2006; Pagani et al., 2006), or to represent a positive feedback to warming, for example through the melting of submarine methane hydrates (Dickens et al., 1995; Sluijs et al., 2007b).

Although warming and perturbations in the hydrological cycle during the PETM as a whole is relatively well documented, not much is known about climate changes during the PETM. Generally, biotic and geochemical records suggest a relatively uniform, warm climate state over the span of the PETM. At least partially, this is due to many studies using extremely condensed deep-sea sediment sections, where bioturbation has potentially blurred signals and carbonate dissolution reduced temporal resolution, particularly for the onset of the event (Zachos et al., 2005). Expanded sections show much more detail; for example, continental sections comprised of stacked paleosols such as those in the Bighorn Basin, Wyoming, USA, have high accumulation rates and have revealed wet and dry phases (Bowen et al., 2004; Wing et al., 2005; Kraus and Riggins, 2007), as well as precession-forced variations in hydrology (Abdul Aziz et al., 2008) within the PETM.

In the marine realm, notably oil exploration and production companies have retrieved many high accumulation rate PETM sections from the continental shelves. Both from internal company reports, as well as the comparatively few marginal marine sections from which biogeological data are publically available it has become clear that among morphologically recognizable remains of eukaryotic planktonic biota, the dinoflagellates exhibit the most dramatic response across the PETM (Sluijs et al., 2007a). This is most notably shown by the quasi-globally recorded acme of the organic cysts (or dinocysts) of the thermophilous, and possibly heterotrophic taxon Apectodinium (Bujak and Brinkhuis, 1998; Crouch et al., 2003a; Crouch et al., 2001; Egger et al., 2003). Recent studies have focussed on high-accumulation rate, expanded marginal marine PETM cores from New Jersey, USA, named "Wilson Lake" (Gibbs et al., 2006; Zachos et al., 2006) and "Bass River" (Cramer et al., 1999), drilled by the United States Geological Survey (USGS) and the Ocean Drilling Program (ODP), respectively (Fig. 1). These studies showed that the onset of the Apectodinium acme represents the earliest sign of anomalous PETM-related environmental change, since it occurred several kyrs prior to the onset of warming and the subsequent initiation of the CIE (Sluijs et al., 2007b).

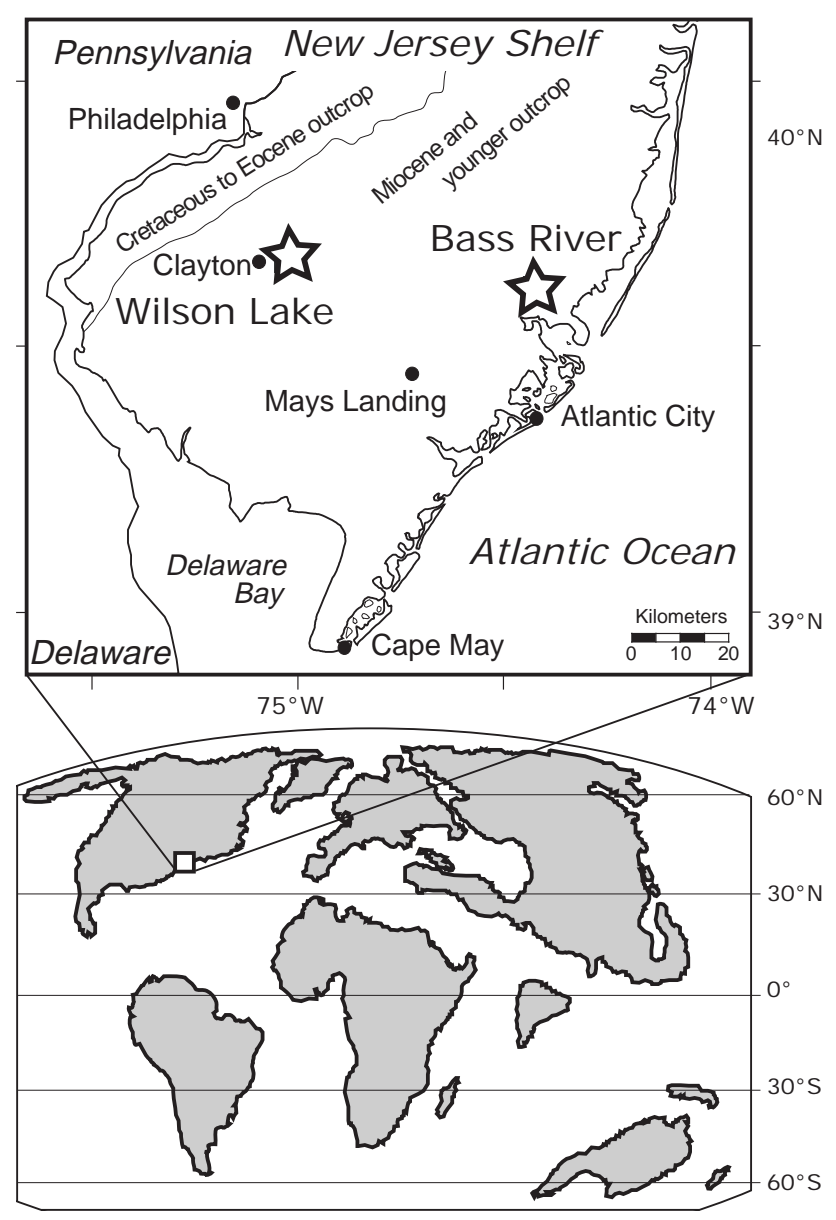

Fig. 1. Locations of the Wilson Lake and Bass River cores. Modified from Miller (1997) and Scotese (1992) for the top and bottom parts, respectively.

Since sediment accumulation rates were $\sim 10 \mathrm{~cm} / \mathrm{kyr}$ across the PETM on the New Jersey Shelf, on average, these sections are potentially well suited to assess infraPETM climate dynamics. Here we provide a paleoecological evaluation of the PETM by using dinocyst distribution patterns set against the background of the combined multidisciplinary New Jersey paleoenvironmental datasets related to sea surface temperature (planktonic foraminifer $\delta^{18} \mathrm{O}$, $\mathrm{TEX}_{86}$ ), energy level of the sedimentary environment (bulk sediment grain size), productivity (calcareous nannofossils) and river supply of terrigenous matter (Branched and Isoprenoid Tetraether (BIT) index, and clay flux data). With this approach, we aim to detect environmental trends within the PETM to eventually contribute to the understanding of processes that underly this event, and the effects of rapid global warming and exogenic carbon release during greenhouse conditions. 


\section{Material and methods}

\subsection{Material}

The Bass River core $\left(39^{\circ} 36^{\prime} 42^{\prime \prime} \mathrm{N}, 74^{\circ} 26^{\prime} 12^{\prime \prime} \mathrm{W}\right)$ was drilled in Bass River State Forest, New Jersey, during ODP Leg 174AX in 1996 (Miller et al., 1998). The Wilson Lake core $\left(39^{\circ} 39^{\prime} \mathrm{N}, 75^{\circ} 03^{\prime} \mathrm{W}\right)$ was drilled by the USGS in 2000 and is located approximately $30 \mathrm{~km}$ west of Bass River. Wilson Lake was, hence, located closer to the paleoshoreline than Bass River. Previously published lithological and micropaleontological information indicates that the New Jersey sites were located on the shelf during the PETM (Gibson et al., 1993, 2000). Uppermost Paleocene sediments of the Vincetown Formation at both sites are relatively condensed (average sedimentation rates of $\sim 1 \mathrm{~cm} \mathrm{kyr}^{-1}$ ) and consist of glauconite-bearing siltstones, interpreted as a transgressive systems tract (Liu et al., 1997; Cramer et al., 1999) (Figs. 2, $3)$. The PETM was previously identified at both sites, based on the CIE in calcite and dinocyst $\delta^{13} \mathrm{C}$ records (Cramer et al., 1999). Based on these records, the onset of the CIE is at 357.3 meters below surface (mbs) at Bass River (Fig. 2). In the $\delta^{13} \mathrm{C}$ record measured on bulk carbonate (BC) at Wilson Lake, the base of the CIE is not as clearly marked as at Bass River, primarily due to the absence of carbonate between $\sim 109.3$ and $\sim 109.8$ mbs (Fig. 3). The $\delta^{13} \mathrm{C}$ record measured on dinocysts (DINO) shows background late Palaeocene values up to $\sim 110.0 \mathrm{mbs}$. At this level the transition to true CIE values starts, coinciding with a negative step in the $\delta^{13} \mathrm{C}_{\mathrm{BC}}$ record, together implying the base of the CIE to be at this level (Sluijs et al., 2007b). The onset of the CIEs marks the transition to the Manasquan Formation, and the entire CIE is rich in clay, particularly kaolinite, and devoid of any siliciclastic coarse fraction (Cramer et al., 1999). The CIEs comprise very expanded deposits that exhibit sedimentation rates of approximately 8-10 $\mathrm{cm} \mathrm{kyr}^{-1}$ (Gibbs et al., 2006; Sluijs et al., 2007b; John et al., 2008). The upper part of the CIE is truncated by a sequence boundary at both sites, and sediments overlying this interval are at least $2 \mathrm{Myr}$ younger than the PETM (Cramer et al., 1999).

\subsection{Methods}

\section{Processing and analyses}

Palynological processing was performed using standard methods described in Sluijs et al. (2003). Briefly, $\sim 10 \mathrm{~g}$ of freeze-dried sample, spiked with a known amount of $L y$ copodium spores, was treated with $30 \% \mathrm{HCl}$ and twice with $38 \%$ HF for carbonate and silicate removal, respectively. Residues were sieved using a $15-\mu \mathrm{m}$ nylon mesh, and subsequently mounted on microscope slides and analyzed under 500x magnification. Raw dinocyst data are available in the supplement, see: http://www.biogeosciences.net/6/1755/ 2009/bg-6-1755-2009-supplement.zip. All slides, including type materials, are lodged in the collection of the Laboratory of Palaeobotany and Palynology, Utrecht University, The Netherlands.

\section{Dinoflagellate cyst ecology and grouping of taxa}

Less than $20 \%$ of living dinoflagellate species produce "fossilizable" organic walled cysts, or "dinocysts" (Fensome et al., 1996a). It is generally assumed that most of these fossil organic dinocysts represent the hypnozygotic stage of a dinoflagellate species. Organic cysts of dinoflagellates can be traced back to the motile stage (theca) through laboratory incubation experiments (e.g., Rochon et al., 2009). Increasingly, it is made clear that at least several Recent dinoflagellate species may produce various cyst "morphotypes" depending on the physicochemical parameters of the water mass in which the theca develops or because of other, unknown ecological and/or biological, incl. genetic aspects (Ellegaard, 2000; Hallett, 1999). In the absence of fossilized genetic materials and/or relevant DNA/RNA studies, paleontologists have based dinocyst taxonomy on even the smallest of morphological details observed in/on fossil remains. Unfortunately, seen in the light of the incubation experiments, it is notoriously difficult, if not impossible, to determine the true biological and/or ecological relevance of such details. Yet, in order to extract meaningful paleoecological information from fossil dinoflagellate remains, it is vital to establish whether recorded specimens represent relatively consistent biological or even ecological entities or not. Here, in order to at least assess some possible ecological relationships between apparently changing physicochemical parameters and dinocyst paleoecology we take an approach that is founded on largely empirically based grouping of morphologically closely related forms. These taxa may either be strictly, or loosely defined accepted "species", groups of "species" within genera, genera themselves, or even groups of genera (cf., Brinkhuis, 1994; Pross and Brinkhuis, 2005; Sluijs et al., 2005). Next, we assume that any given high relative and/or high absolute abundance of these taxa per unit time reflects (sub) optimal environmental conditions and/or wider tolerance towards certain environmental conditions for such taxa. For example, a monotypic assemblage is taken to indicate that only that specific taxon was able to cope with apparently restricted marine conditions.

For practical purposes, we follow the nomenclature cited in Fensome and Williams (2004). In the taxonomic section, we present the rationale for the established "eco" taxa employed herein.

\section{Statistical analyses}

For paleoenvironmental analyses we carry out correspondence analyses similar to those presented in Pross and Schmiedl (2002) and Dale et al. (2005). Principle component (PCA) and canonical correspondence analyses (CCA) 

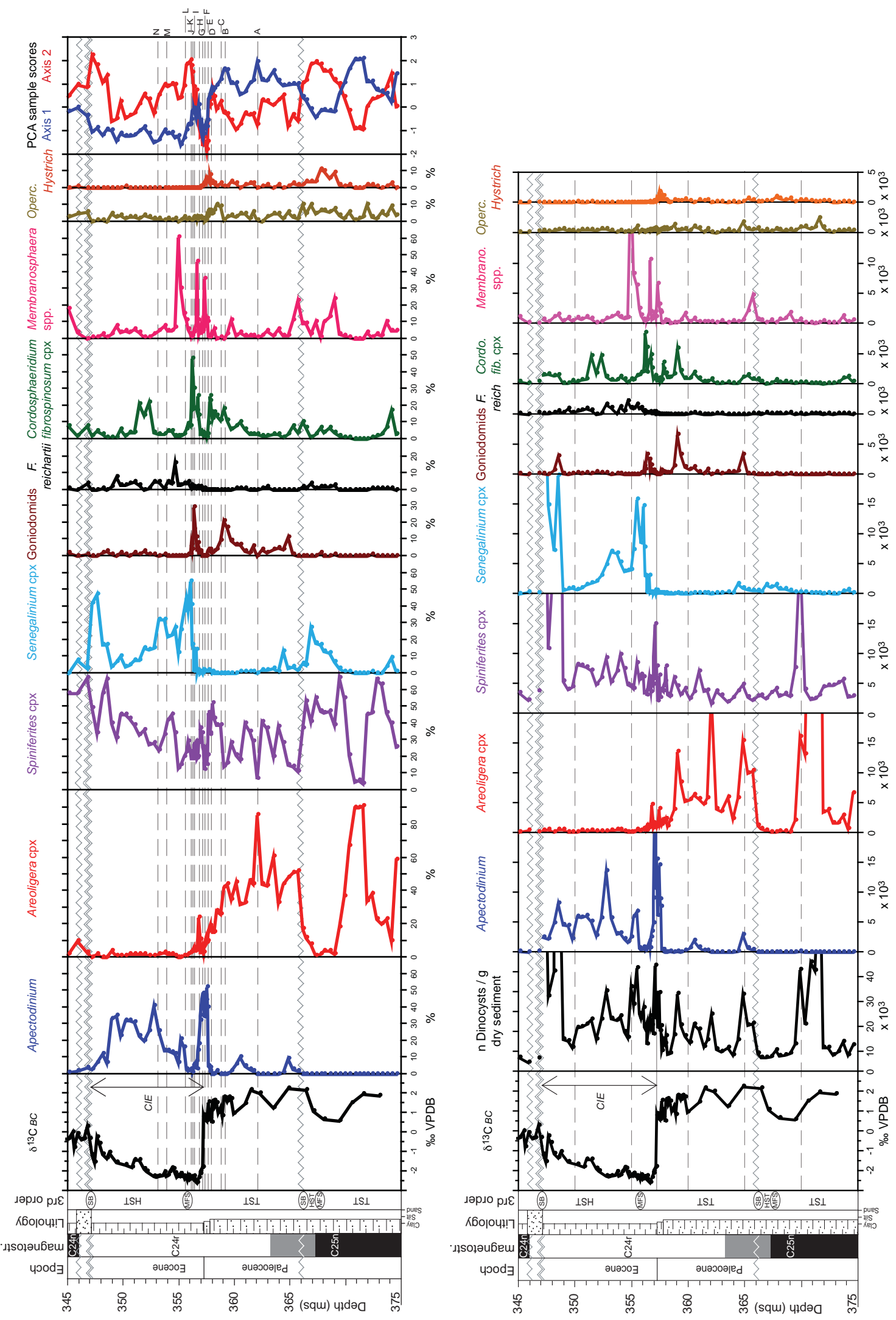

Fig. 2. Dinocyst distribution across the Late Paleocene - Early Eocene at Bass River. (A) Relative abundances (percentages). Letters refer to dinocyst events listed in Table 1. (B) Absolute quantitative results. 

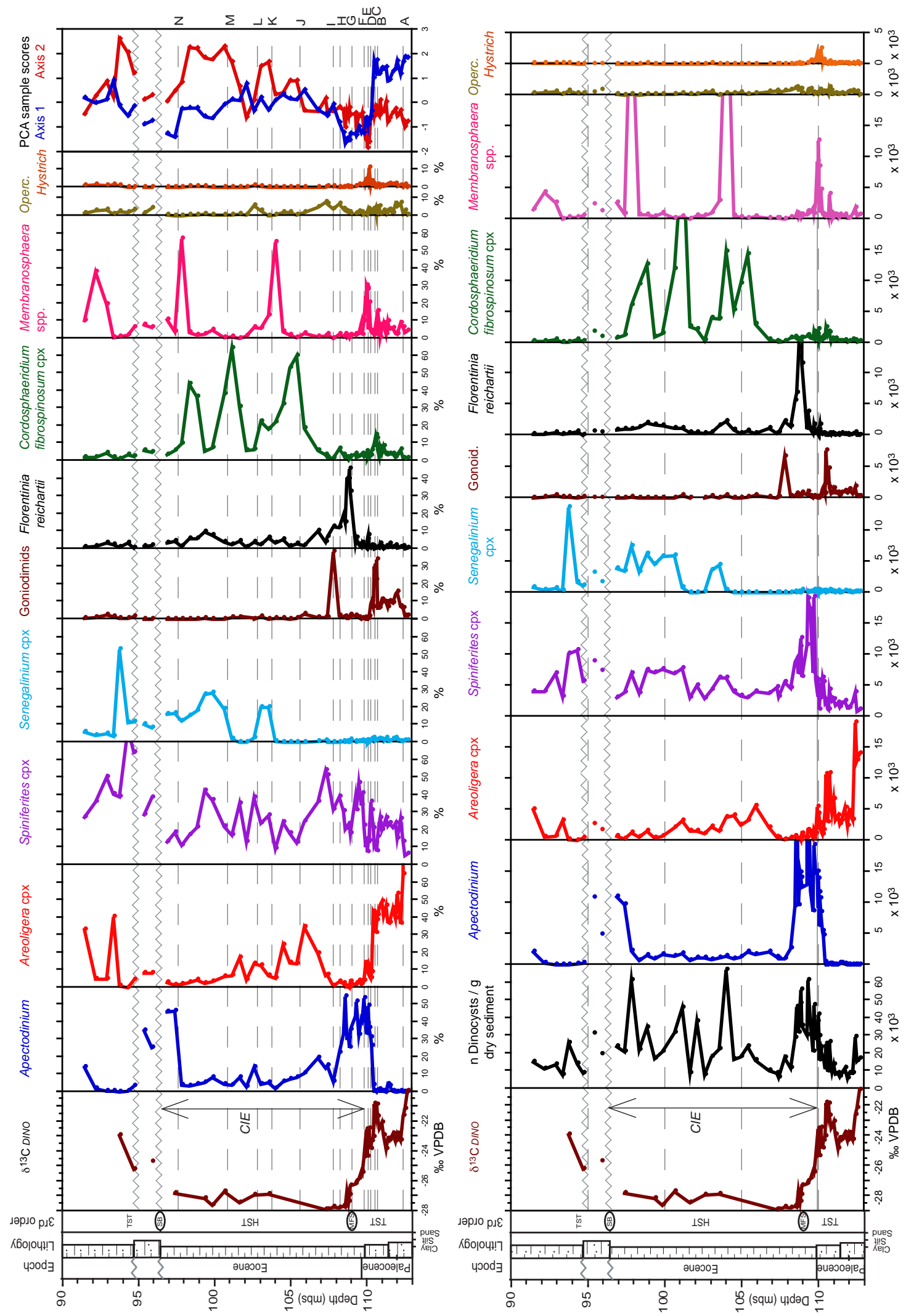

Fig. 3. Dinocyst distribution across the Late Paleocene - Early Eocene at Wilson Lake. (A) Relative abundances (percentages). Letters refer to dinocyst events listed in Table 1. (B) Absolute quantitative results. 
were done using the software package Canoco (ter Braak and Smilauer, 2002). With the CCAs we aim to assess correspondence of dinocyst taxa with the environmental parameters sea surface temperature (TEX 86 ; (Sluijs et al., 2007b; Zachos et al., 2006), energy level of the environment ( $>63 \mu \mathrm{m}$ sediment fraction; (John et al., 2008), input of terrestrial organic matter (BIT; Sluijs et al., 2008a) and the abundance of metals (MS) in the sediment. This will be done to gain better insight in the paleoecological preferences of the dinoflagellates.

\section{Results}

\subsection{Dinocyst distribution patterns}

Dinocyst assemblages are very similar in both relative and absolute abundances between Bass River and Wilson Lake, and generally comprise taxa commonly recorded in midlatitude marginal marine lower Paleogene sediments (Figs. 2, 3 and supplement: http://www.biogeosciences.net/6/1755/ 2009/bg-6-1755-2009-supplement.zip). Late Paleocene assemblages are either dominated by representatives of the typically open marine Spiniferites complex, or by members of the Areoligera complex (Figs. 2, 3). We have recorded transient abundances of representatives of the family Goniodomaceae, particularly Eocladopyxis spp., but also Heteraulacacysta spp. and Polysphaeridium spp. These are widely considered to be characteristic of restricted marine, usually lagoonal, settings with generally high, but also (seasonally) variable salinities in the Quaternary (Reichart et al., 2004) and the Paleogene (Brinkhuis, 1994). Approximately 5 kyrs prior to the onset of the CIE, specimens assignable to Apectodinium spp. become dominant (Sluijs et al., 2007b). Particularly within the PETM, representatives of a suite of morphologically closely related peridinioid genera are abundant (particularly those assignable to Senegalinium and Phthanoperidinium), a group that in general tolerated very low surface water salinities (Brinkhuis et al., 2006; Röhl et al., 2004; Sluijs et al., 2006, 2007b, 2008b), and likely preferred high nutrient and/or food supply (e.g., Dale and Fjellså, 1994; Sluijs et al., 2005). Additional locally common to abundant taxa include Cordosphaeridium spp., Membranosphaera spp., Hystrichosphaeridium tubiferum, Operculodinium spp., and a new species of Florentinia.

\subsection{Site-to-site correlation}

Prior to the PETM, assemblages both at Wilson Lake and Bass River are dominated by representatives of Areoligera, but diversity increases within the PETM. Because the sites are only $\sim 30 \mathrm{~km}$ apart, changes in dinocyst assemblages on these timescales should be concomitant between these sites if they represent regional rather than local changes in environment. Therefore, the various shifts allows a much more detailed correlation of dinocyst-defined events than can be achieved by carbon isotope stratigraphy (Table 1). Even

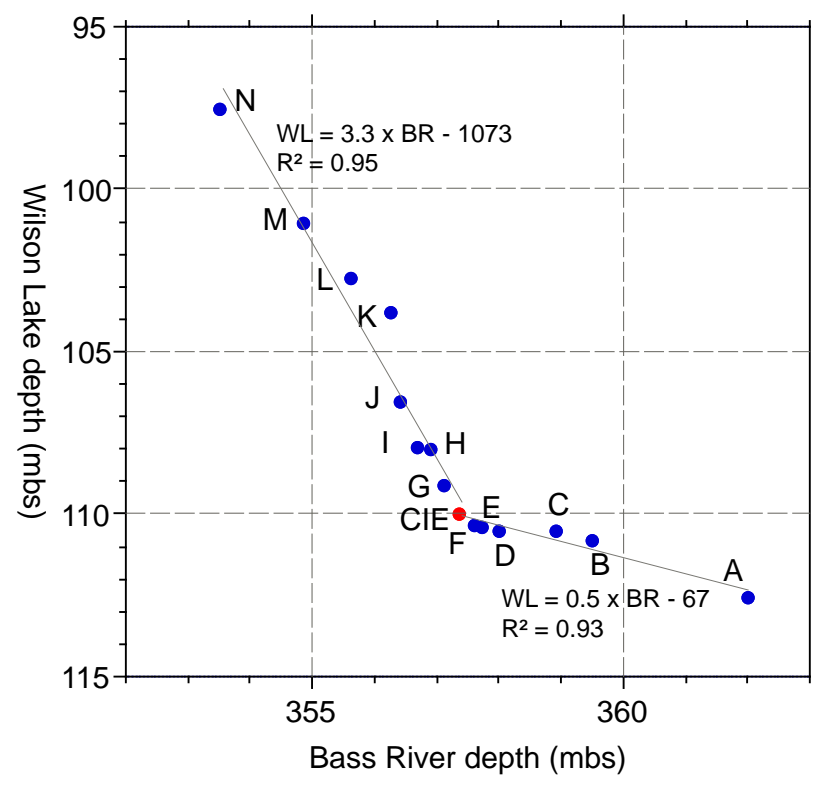

Fig. 4. Depth-depth plot based on dinocyst events (Table 1) indicating relative sedimentation rates between Wilson Lake and Bass River.

though some of these correlations are tentative, they are stratigraphically consistent and indicate that the dinocyst assemblage changes reflect environmental change on a regional scale. According to this correlation, events D through K occur within 2 meters at Bass River but span $\sim 6 \mathrm{~m}$ at Wilson Lake, indicating condensation at Bass River relative to Wilson Lake during the time of deposition (Fig. 4). Because the sequence of events is the same for both sites across the onset of the PETM, it is likely that both sites are complete in this interval and there is no sign of a hiatus at Bass River as was hypothesized by John et al. (2008). Moreover, at Wilson Lake, the 2 Myr hiatus occurs approximately $1 \mathrm{~m}$ above event $\mathrm{N}$, while the PETM continues for another $6 \mathrm{~m}$ at Bass River. This implies that more of the PETM is present at Bass River than at Wilson Lake.

\subsection{Statistical analyses}

The similarity in dinocyst assemblages between Wilson Lake and Bass River is confirmed by the PCA analyses on relative abundances (Fig. 5a). For both sites the PCAs clearly separate the Areoligera, Apectodinium and Senegalinium complexes along axes 1 and 2. Also most other taxa mutually plot in similar directions, e.g., Goniodomids and Operculodinium plot in a similar direction as Areoligera. For further comparison between the sites, we carried out a PCA combining the Wilson Lake and Bass River data (Fig. 5b) and included the sample scores of Axis 1 and Axis 2 in Figs. 2a and 3a. The patterns in this PCA are similar to the PCAs of the individual sites. 
Table 1. Dinocyst events recognized at Bass River and Wilson Lake.

\begin{tabular}{|c|c|c|c|c|c|c|}
\hline Event & Description & Remarks & $\begin{array}{r}\text { Onset Bass } \\
\text { River } \\
(\mathrm{mbs})\end{array}$ & $\begin{array}{r}\text { Termination } \\
\text { Bass River } \\
(\mathrm{mbs})\end{array}$ & $\begin{array}{r}\text { Onset Wilson } \\
\text { Lake } \\
(\mathrm{mbs})\end{array}$ & $\begin{array}{l}\text { Termination } \\
\text { Wilson Lake } \\
(\mathrm{mbs})\end{array}$ \\
\hline A & $\begin{array}{l}\text { sharp decrease }(>70 \%-40 \%) \text { in the } \\
\text { abundance of Areoligera }\end{array}$ & & 362.00 & & 112.55 & \\
\hline B & $\begin{array}{l}\text { short-lived acme of Goniodomid } \\
\text { taxa }\end{array}$ & & 359.50 & 359.00 & 110.80 & 110.60 \\
\hline $\mathrm{C}$ & $\begin{array}{l}\text { second decrease in Areoligera } \\
\text { abundance }\end{array}$ & & 358.90 & & 110.50 & \\
\hline $\mathrm{D}$ & $\begin{array}{l}\text { short-lived abundance of } \\
\text { Hystrichosphaeridium }\end{array}$ & & 358.00 & 357.40 & 110.50 & 110.00 \\
\hline $\mathrm{E}$ & $\begin{array}{l}\text { the onset of the Apectodinium } \\
\text { acme }\end{array}$ & & 357.70 & & 110.40 & \\
\hline $\mathrm{F}$ & abundance of Membranosphaera & tentative correlation & 357.60 & 357.30 & 110.30 & 109.90 \\
\hline CIE & & & 357.35 & & 110.00 & \\
\hline $\mathrm{G}$ & $\begin{array}{l}\text { abundance of Florentinia } \\
\text { reichartii }\end{array}$ & $\begin{array}{l}\text { tentative correlation, not truly } \\
\text { unambiguous at Bass River }\end{array}$ & 357.10 & & 109.10 & 108.30 \\
\hline $\mathrm{H}$ & $\begin{array}{l}\text { rapid decrease in Apectodinium } \\
\text { abundance }\end{array}$ & & 356.90 & & 108.00 & \\
\hline I & $\begin{array}{l}\text { short-lived acme of Goniodomid } \\
\text { taxa }\end{array}$ & & 356.67 & 356.35 & 107.90 & \\
\hline $\mathrm{J}$ & abundance of Cordosphaeridium & tentative correlation & 356.40 & 356.15 & 106.50 & 103.00 \\
\hline K & $\begin{array}{l}\text { onset of abundant Senegalinium } \\
\text { cpx (low salinity-tolerant) }\end{array}$ & & 356.25 & & 103.80 & \\
\hline $\mathrm{L}$ & $\begin{array}{l}\text { pulse in Apectodinium } \\
\text { abundance }\end{array}$ & $\begin{array}{l}\text { tentative correlation, not truly } \\
\text { unambiguous at Wilson Lake }\end{array}$ & 355.60 & 355.10 & 102.70 & 102.60 \\
\hline M & $\begin{array}{l}\text { second increase in Senegalinium } \\
\text { cpx (low salinity-tolerant) }\end{array}$ & & 354.85 & & 101.00 & \\
\hline $\mathrm{N}$ & $\begin{array}{l}\text { increase in Apectodinium } \\
\text { abundance }\end{array}$ & & 353.50 & & 97.50 & \\
\hline
\end{tabular}

CCA analyses also show congruent patterns between Wilson Lake and Bass River (Fig. 6). At both sites, Areoligera and $H$. tubiferum (although abundances are relatively low in the assemblages for the latter) plot along wt $\%>63 \mu \mathrm{m}$ fraction. At Bass River, the low-salinity-tolerant group plots very close to magnetic susceptibility. Apectodinium generally plots in the same direction as $\mathrm{TEX}_{86}$, although the correlation is not very firm.

\section{Discussion}

\subsection{Apectodinium paleoecology}

The biotic response of dinocysts to the PETM is particularly interesting because it includes a quasi-global acme of Apectodinium spp., thereby comprising usually $>40 \%$ of the dinocyst assemblage (Heilmann-Clausen, 1985; Powell et al., 1996; Bujak and Brinkhuis, 1998; Heilmann-Clausen and Egger, 2000). Such a global, synchronous acme is unique in the dinocyst fossil record spanning the late Triassic to the Recent.

\subsubsection{Temperature}

In the CCAs, Apectodinium correlates best, although still weakly, with temperature. It plots in different directions to the low-salinity-tolerant group, and the inner neritic Areoligera complex. The taxon Apectodinium originated close to the Danian-Selandian boundary (Brinkhuis et al., 1994), and abundant occurrences remained largely restricted to low latitudes throughout the Palaeocene (Bujak and Brinkhuis, 1998). It has been hypothesized that temperate to polar sea surface temperatures increased to allow poleward migration of Apectodinium during the PETM (Bujak and Brinkhuis, 1998; Crouch et al., 2001; Sluijs et al., 2006). However, recently it was shown that temperatures in mid-latitude regions, incl. New Jersey, were probably already high enough during the Late Paleocene to allow for abundant Apectodinium (Zachos et al., 2006; Sluijs et al., 2007b). This indicates 

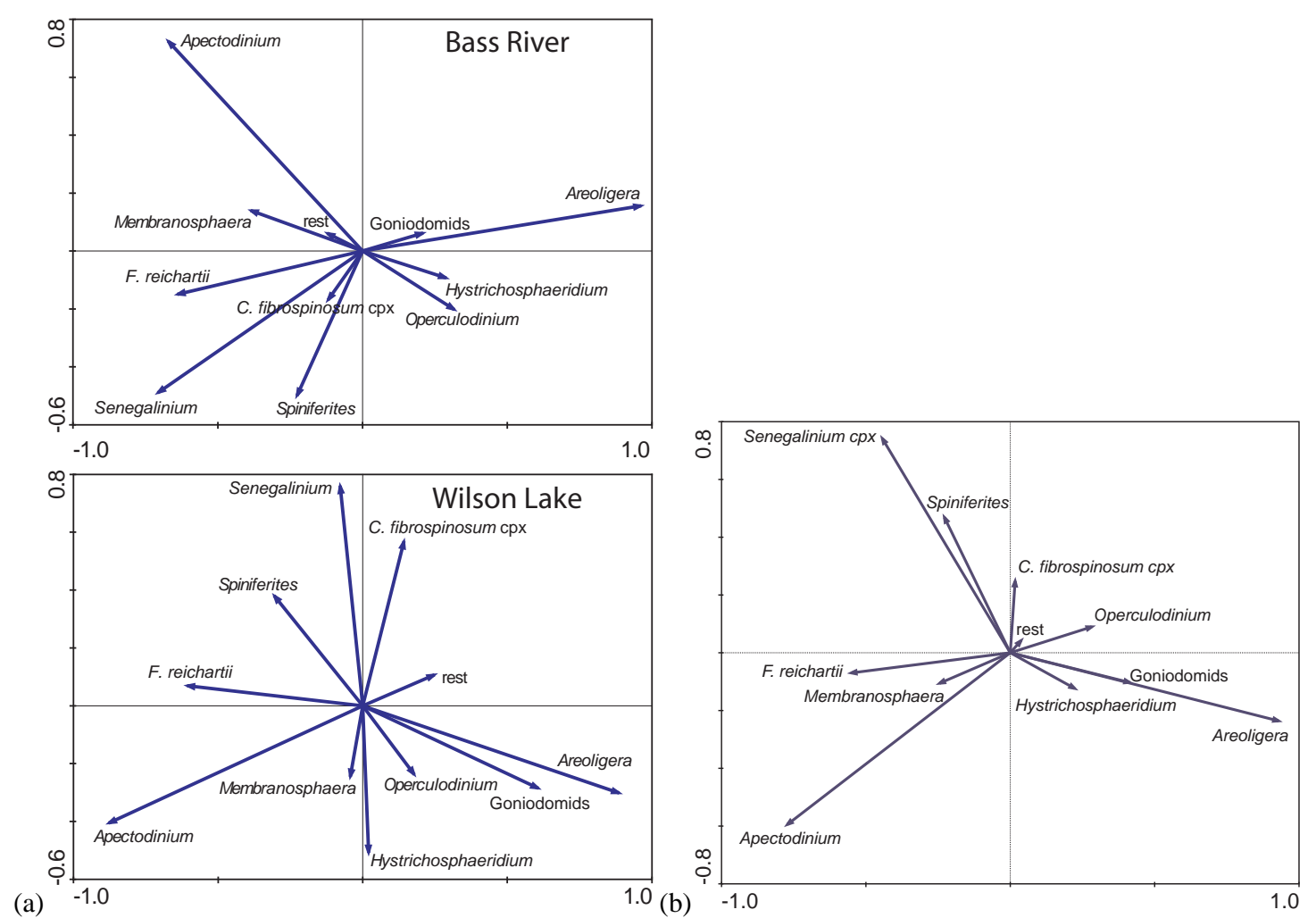

Fig. 5. Principle Component Analysis scatter plots. (A) Bass River and Wilson Lake; (B) combined Bass River and Wilson Lake.

that factors other than temperature prevented mid-latitude abundances of this taxon at that time (Sluijs et al., 2007b). Moreover, the onset of the Apectodinium acme in New Jersey occurred prior to the onset of the rise in mean annual temperature (MAT), suggesting that (an) additional environmental factor(s) triggered the acme in this region (Sluijs et al., 2007b). However, many dinoflagellates bloom in a particular season (e.g., Dale, 2001), implying that proliferation of Apectodinium may have been initiated by environmental change (such as warming or stratification) of one critical season, thereby not significantly influencing MAT. In effect, there is the option that the apparently massive abundance actually only reflects $2-3$ anomalous weeks per year (Fensome et al., 1996b).

\subsubsection{Salinity}

Most representatives of Apectodinium were likely also euryhaline, although truly brackish conditions were perhaps not optimal (Sluijs et al., 2007b, 2008b). While in midlatitude regions Apectodinium contributes at least $40 \%$ of the assemblage for much of the PETM (Figs. 2, 3) (HeilmannClausen, 1985; Powell et al., 1996; Bujak and Brinkhuis, 1998; Heilmann-Clausen and Egger, 2000), Apectodinium abundances only reach to $\sim 20 \%$ in the Arctic, where typical low-salinity-tolerant dinocysts remain dominant (Sluijs et al., 2008b). Similar trends are recorded at Bass River and Wil- son Lake, where Apectodinium spp. became outnumbered by typical low salinity-tolerant dinocysts during phases of the PETM (Figs. 2, 3). Moreover, Apectodinium spp. do not plot closely to the low-salinity-tolerant dinocysts in the PCA. This indicates that while Apectodinium was reasonably successful at relatively low salinities, such as in the Arctic during the PETM (Sluijs et al., 2008b), other taxa were able to dominate dinocyst assemblages under such ecological conditions.

\subsubsection{Heterotrophy}

Several authors have suggested that the dinoflagellates that formed Apectodinium cysts may have been heterotrophic and fed on organic detritus or other plankton (Bujak and Brinkhuis, 1998; Crouch et al., 2001, 2003b; Sluijs et al., 2005, 2007b). This suggestion was primarily based on the fact that Apectodinium exhibits some similarities in the plate organization, a critical tool in taxonomical classification, with extant heterotrophic dinoflagellates (Evitt, 1985; Lentin and Vozzhennikova, 1989; Fensome et al., 1996b). Discussion also exists on whether Apectodinium and its family Wetzeliellioidae are related to the Recent, mainly diatom feeding (Buskey, 1997) genus Protoperidinium.

At both Wilson Lake and Bass River we have recorded many Apectodinium specimens that have the typical brown color usually observed in cysts of Recent members of 
Protoperidinium (Plate 1I-L). This implies that, along with some systematic resemblances, the Apectodinium cyst wall materials are very similar to Protoperidinium cysts. Hence, although morphological differences remain between Recent cysts of heterotrophic dinoflagellates and Apectodinium, this could be taken as an additional line of evidence that Apectodinium was a heterotrophic dinoflagellate.

The question whether Apectodinium was heterotrophic or not is critical, because the nutrient load of an ecosystem is usually well reflected in the abundance of heterotrophs versus autotrophs. Nutrient-rich conditions are required to sustain abundant heterotrophs in an ecosystem because of the loss of energy in subsequent stages of the food chain. Its presumed heterotrophic lifestyle implies that Apectodinium, similar to Recent Protoperidinium, was dependent on the availability of prey (perhaps diatoms, or other [even zoo-] plankton) that are, in turn, dependent on nutrient availability (particularly nitrogen and phosphorus). Hence, if it was heterotrophic, the global nature of the Apectodinium acme during the PETM (Sluijs et al., 2007a) suggests that shallow seas around the globe exhibited a strong increase in nutrient availability, or some food source (Powell et al., 1996; Bujak and Brinkhuis, 1998; Crouch et al., 2001, 2003a; Crouch and Brinkhuis, 2005; Sluijs et al., 2005). Locally, elevated nearcoast productivity at the PETM has been suggested to explain benthic foraminiferal and calcareous nannofossil assemblage changes as well as organic-rich sediments in marginal marine realms (e.g., Thomas and Shackleton, 1996; Speijer and Schmitz, 1998; Gavrilov et al., 2003; Gibbs et al., 2006; Sluijs et al., 2006, 2008b; see overview in Sluijs et al., 2007a).

The mechanism behind global eutrophication of at least shallow seas is as yet unclear. It has been suggested that the global warming associated with the PETM triggered intensification of weathering, the hydrological cycle and run off in many regions around the world (Robert and Kennett, 1994; Ravizza et al., 2001; Schmitz et al., 2001; Crouch et al., 2003b; Hollis et al., 2005; Giusberti et al., 2007; Nicolo et al., 2007; Sluijs et al., 2007b). The increase in clay supply to the New Jersey shelf (and many other regions; see Sluijs et al. (2008a) for an overview) supports such a scenario. However, the low amount of terrestrial palynomorphs throughout the section hampers the evaluation of changes in the flux of terrestrial material on the New Jersey Shelf. An alternative mechanism of eutrophication is related to hurricanes. Modeling studies have suggested intensification of storms in an extreme greenhouse world (Emanuel, 2005; Emanuel et al., 2004; Sriver and Huber, 2007). If more intense storms occurred during the PETM compared to background conditions, they should have caused mixing of deeper nutrient-rich waters into the photic zone on a regional scale thereby promoting primary production.

Because the fossil record probably only represents a very small percentage of the surface water assemblages, it is hard to reconstruct a relatively complete food web for the PETM.

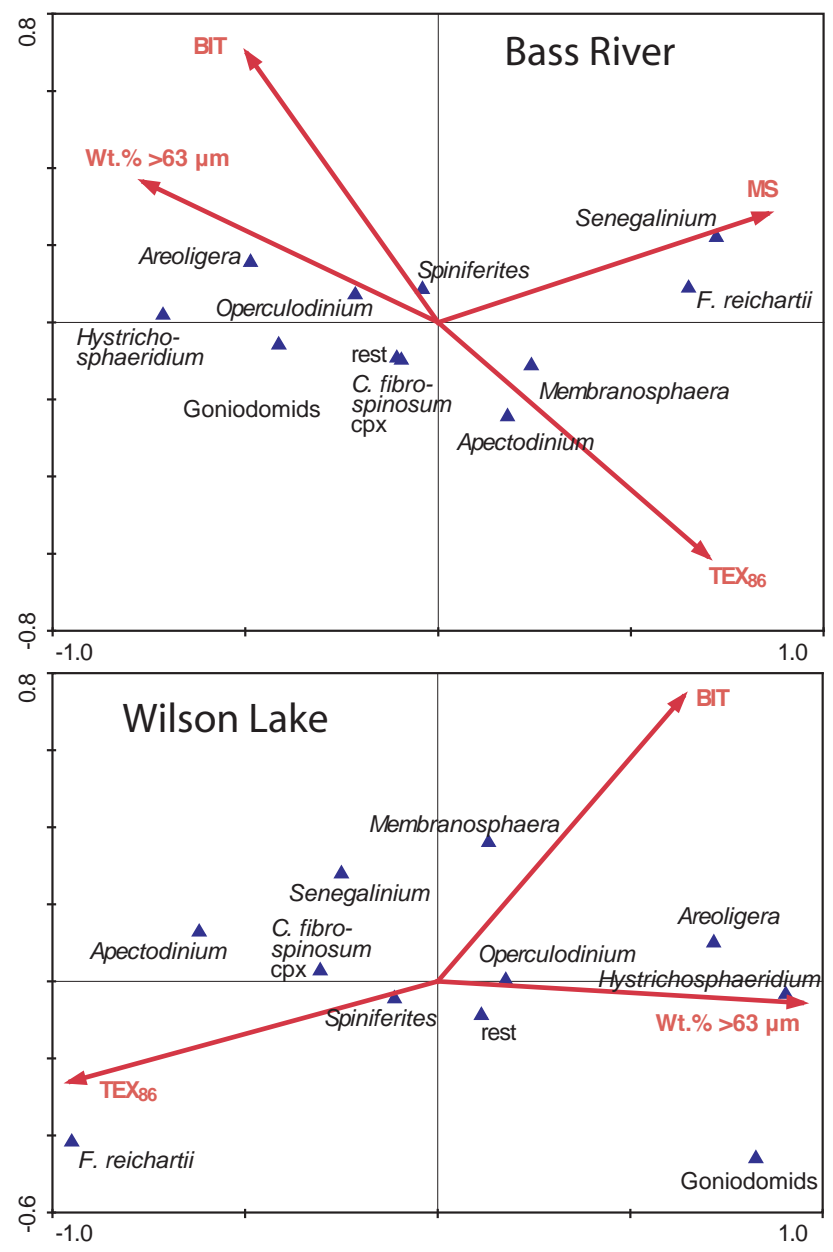

Fig. 6. Canonical Correspondence Analysis scatter plots.

Therefore it is equally difficult to identify the exact food source of Apectodinium and to unequivocally show it was auto- or heterotrophic. Regardless of these unanswered questions on its nature, the acme directly implies that the food source of Apectodinium was globally very abundant in shallow marine settings. If it was heterotrophic, the acme implies that the global marginal marine ocean became enriched in nutrients and food.

\subsubsection{Which other critical factor?}

A baseline requirement for the distribution of Apectodinium appears to have been high temperatures. Apectodinium acmes have been recorded from upper Paleocene deposits in the Tethyan Ocean (Powell et al., 1996; Bujak and Brinkhuis, 1998; Iakovleva et al., 2001), suggesting that conditions there were episodically and locally similar to those on a global scale during the PETM (Crouch et al., 2003a). Similar to other mid-latitude regions, Apectodinium was already present on the New Jersey Shelf at least since Chron C25n times (Fig. 2); yet, in contrast to low-latitude sites (Iakovleva 
et al., 2001) no pre-PETM acmes have been reported from such regions. Moreover, food availability and salinity, and/or stratification seem important. Although these parameters were likely important for the distribution of Apectodinium, it appears that even a combination of these factors was likely not truly unique in the early Paleogene at mid latitudes. This suggests that some critical other environmental factor(s) that stimulated massive Apectodinium production has not yet been identified. Somehow, however, this unidentified factor was related to the PETM. Whichever combination of surface water parameters caused the global acme of Apectodinium, it is consistently associated with the PETM and appears to signify a harbinger to global warming and carbon injection as the acme started just prior to the PETM warming and the CIE in mid-latitude areas (Sluijs et al., 2007b).

\subsection{Areoligera and transgression}

Much empirical evidence suggests that a dominance of the Areoligera complex indicates inner neritic, high energy environments (Brinkhuis, 1994; Pross and Brinkhuis, 2005), while the Spiniferites complex is mostly recorded from neritic deposits with increasing relative abundances at outer neritic localities (Brinkhuis, 1994; Pross and Brinkhuis, 2005). This evidence was previously used to infer a late Paleocene transgression in New Jersey by applying the ratio between Spiniferites and Areoligera abundances (Sluijs et al., 2008a). In the CCA analyses (Fig. 6), Areoligera shows a significant correlation with the wt $\%$ coarse fraction of the sediment, which had been previously been used to identify a phase of transgression (Liu et al., 1997; Cramer et al., 1999). Spiniferites does not correlate to any proxy data in the CCAs, supporting the inference that they inhabited all areas on the shelf during the Paleogene, much like today (Wall et al., 1977). In New Jersey, and also in other regions, abundant Areoligera appears consistently related to third order transgressive systems tracts in sequence stratigraphic terms, and thus sea level rise in neritic settings (e.g., Crouch and Brinkhuis, 2005; Iakovleva et al., 2001; Sluijs et al., 2008a).

Hence, in a manner similar to the Spiniferites/Aeroligera ratio (Sluijs et al., 2008a), the sample scores for Axis 1 of the PCA at Bass River and Wilson Lake should in part reflect sea level (Fig. 2). The recorded trends are consistent with a transgression during the PETM, a phenomenon recorded on a global scale (Sluijs et al., 2008a).

\subsection{Fresh water forcing}

Axis 2 in all PCAs is dominated by the abundances of the low-salinity-tolerant group, making it an indicator for low salinity. In the CCA, the low-salinity-tolerant group corresponds closely to magnetic susceptibility (MS) of the sediment at Bass River. The MS values are dominantly controlled by abundances of biogenic magnetic particles, produced by bacteria (Kopp et al., 2007; Lippert and Zachos,
2007). These bacteria thrive in a particular niche, as they require low oxygen concentrations and a high supply of iron $\left(\mathrm{Fe}^{2+}\right)$. However, conditions were not euxinic because free sulfide dissolves bacterial magnetite (Canfield and Berner, 1987; Dickens, 2008). These specific requirements suggest that high fluxes of organic carbon to the sea floor to supply the $\mathrm{Fe}^{2+}$, but the magnetic grains were not subject to sulfidic conditions because the sediments were deposited on top of oxygenated uppermost Paleocene sediments (Dickens, 2008). This scenario requires a significant increase in runoff and production rates (Lippert and Zachos, 2007), which is consistent with the vast increase in clay sedimentation (Cramer et al., 1999; John et al., 2008) as well as with the strong positive correlation between MS and the Senegalinium complex, which not only suggests low salinities, but also high food/nutrient supply (Sluijs et al., 2007b).

This supports previous inferences (Brinkhuis et al., 2006; Sluijs et al., 2006, 2007b, 2008b) that many hexaperidinioids, particularly Senegalinium and Phthanoperidinium, but also Deflandrea, Cerodinium, Spinidinium and related genera (Sluijs et al., 2009), were indeed tolerant of low salinities and flourished best during episodes of abundant nutrients/food (e.g., Dale and Fjellså, 1994; Firth, 1996; see overview in Sluijs et al., 2005). Abundances of the Senegalinium complex suggest that increased fresh water forcing started some time (perhaps $10 \mathrm{kyr}$, if the cycles in Apectodinium (Fig. 2) are precession-related (Sluijs et al., 2007b), see below) after the onset of the CIE, consistent with a humid climate state at least during the first $\sim 100 \mathrm{kyr}$ of the PETM (e.g., Bowen et al., 2004).

\section{A variable climate state during the PETM?}

Although high abundances of Apectodinium and the Senegalinium complex occur across portions of the New Jersey PETM sections, abundances clearly vary significantly during the PETM. Short-lived acmes of Hystrichosphaeridium, Eocladopyxis spp., Cordosphaeridium fibrospinosum, Membranosphaera spp. and the new species Florentinia reichartii occur throughout the PETM at both Bass River and Wilson Lake both in the relative and absolute quantitative records (Figs. 2 and 3). Such variation is absent in the sediments deposited during the $\sim 1 \mathrm{Ma}$ prior to the PETM. It is unlikely that the record is affected by preferential oxidation of some (peridinioid) taxa, as these are present throughout the record and well preserved. In part, in may be related to winnowing, indicated by the general low abundance of clay and the coarse nature of the sediments, which would concentrate the relatively large taxon Areoligera and reduce abundances of smaller taxa, particularly Senegalinium spp., Phthanoperidinium spp. and Membranosphaera spp. However, the absence of temporal abundances of other typically large taxa, such as specimens of Cordosphaeridium and 
Hystrichosphaeridium, as recorded within the PETM, suggests more stable conditions prior to than during the event.

The cyclic abundances of Apectodinium as recorded within the PETM at Bass River, both as a percentage of the assemblage and numbers per gram sediment, has been suggested to be associated to the precession cycle (Sluijs et al., 2007b). Regardless of the forcing mechanism, maxima in Apectodinium co-occur with maxima in the number of total dinocysts per gram sediment. The cyclic behaviour of total dinocysts and Apectodinium per gram, while absolute abundances of most other taxa remain constant, strongly suggests nutrient/food supply as a cause rather than variations in siliciclastic sediment supply. Assuming constant preservation, which is likely considering persistent suboxic seafloor conditions (Dickens, 2008; Kopp et al., 2007; Lippert and Zachos, 2007), varying nutrient/food abundances controlled the cycles in Apectodinium, consistent with a heterotrophic lifestyle of this taxon.

Peak abundances of representatives of Eocladopyxis, a genus within the family Goniodomaceae that in the Recent is usually associated with low latitude hyposaline or hypersaline lagoonal settings (Bradford and Wall, 1984; Wall et al., 1977), are recorded just prior to and immediately after the onset of the PETM at both Bass River and Wilson Lake (Figs. 2, 3). Perhaps these taxa were transported down the shelf from lagoonal settings, but persistent low abundances of terrestrial organic matter (palynomorphs or biomarkers) invoke another mechanism. Perhaps the establishment of a hot and dry season increased sea surface salinities. In this light, high abundances of the related taxon Polysphaeridium zoharyi, recorded in the central Arabian Sea following North Atlantic Heinrich events (Reichart et al., 2004), are interesting. These abundances were explained by a mechanism of regional warming in winter, preventing a saline surface layer to overturn, causing a "hyperstratified" situation with lagoonaltype conditions in the open ocean (Reichart et al., 2004). Analogously, the establishment of seasonal hyperstratification, with hypersaline and warm surface waters, could explain temporal Eocladopyxis abundances on the New Jersey shelf.

Abundances of Cordosphaeridium fibrospinosum and (a large group of) related taxa often informally referred to by several authors as the $C$. fibrospinosum complex of morphologically highly variable taxa (see taxonomic section) occur abundantly during intervals within the PETM at Bass River and Wilson Lake. Although this complex as a whole has become extinct, it was cosmopolitan and several taxa within this group have been associated with stratified and even brackish conditions (e.g., Pross, 2001; Houben, 2008). Hystrichosphaeridium is also temporally abundant and our CCA analyses plot this species together with Areoligera towards wt $\%$ coarse fraction, suggesting it thrived in relatively high-energy environments. Only little paleoecological information is available for Membranosphaera, although it seems most abundant in higher latitudes (sometimes called Elytro- cysta in Southern Ocean sections (e.g., Brinkhuis et al., 2003; Sluijs et al., 2003), and tolerated relatively low salinities (Sluijs et al., 2008b). Even less information is available for the new species Florentinia reichartii apart from that we have recorded it in marginal marine upper Paleocene - lower Eocene sediments in the Gulf of Mexico and the southwest Pacific we are currently studying (personal observation).

\section{Synthesis/concluding remarks}

Our findings prompt a picture of high environmental variability during the PETM at the New Jersey Shelf, likely related to at least regional climatic variability. Our results strongly suggest that the bulk of the variation we note is due to regional precipitation and runoff fluctuations, rather than the overall warm temperature. Such fluctuations may have led to strong, coupled stratification and salinity changes that may have guided the subsequent abundances of, for example, the Senegalinium, Membranosphaera, and goniodomid groups, Hystrichosphaeridium and $F$. reichartii. The hydrological cycle during the "ultra greenhouse" was apparently highly unstable, at least on a regional scale and on Milankovitch time scales. In this light, it is also remarkable that the relative and absolute abundance of sporomorphs from terrestrial higher plants is low during the PETM in New Jersey. Other mid latitude sites across this time interval around the world yield sometimes extremely abundant pollen and spores (e.g., Crouch et al., 2003b; Harrington, 2003; Steurbaut et al., 2003). One speculation concerning this aspect is that the hydrological or temperature regime of the region was so extreme that no stable vegetation could be established during this time.

This study also indicates the necessity of analyzing more chronostratigraphically well calibrated, high accumulation, marine and terrestrial PETM sites from around the world, principally to determine if the New Jersey climatic variability during the PETM was a regional or a larger scale phenomena.

\section{Taxonomy}

\subsection{Systematic paleontology}

Division Dinoflagellata (Bütschli, 1885) Fensome et al. (1993)

Class Dinophyceae Pascher (1914)

Subclass Peridiniphycidae Fensome et al. (1993)

Order Gonyaulacales Taylor (1980)

Family Gonyaulaceae Lindemann (1928)

Subfamily Cribroperidinioideae Fensome et al. (1993)

Florentinia reichartii sp. nov.

Plate 3F-L, Plate 4A-C

Derivation of name: named for Gert-Jan Reichart, geochemist at Utrecht University, in recognition of his pioneer integrated geochemical and palynological studies. 
Holotype: Plate 4A-C. Specimen with numerous hollow processes, an antapical horn (4A), and an archeopyle involving precingular plate 3" (4A-B) plus all apical plates (see sulcal notch, Plate 4C); paratypes: Plate $3 \mathrm{~F}-\mathrm{G}, 3 \mathrm{H}-\mathrm{I}$, 3J, 3K-L.

Diagnosis: a small species of Florentina with distally closed, hollow, long cone-shaped processes and a short, blunt antapical horn.

Description: small, chorate gonyaulacean cyst, characterized by a small antapical horn, and an archeopyle that involves all apical and sometimes precingular plates. Operculum usually free, but may be partially attached. Central body is psilate and almost transparent. Processes are long, approximately (or sometimes more than) half the size of the main body, are hollow and distally-closed and non-tabular. Some processes may fuse in proximity of the central body. The antapical horn is relatively short, approximately as wide as long, and often barely visible. The archeopyle can only rarely be positively identified as type tA, and may additionally involve plate 4", with a usually detached operculum. Tabulation is barely discernable, either by some degree of clustering of groups of processes, the archeopyle or the antapical horn reflecting 6"', which often constitutes the only consistent marker for orientation.

Discussion: Florentinia reichartii can be easily confused with Lingulodinium machaerophorum or Diphyes spp. during microscope analyses, but these are both usually larger and have precingular archeopyles, while L. machaerophorum also lacks an antapical horn. F. reichartii is much smaller than most other species within the genus, and its antapical horn is small relative to the size of the central body. Within the genus Florentinia, it bears closest resemblance to the much larger $F$. ferox, because processes may also fuse in proximity of the central body to create process-complexes. However, F. ferox has more proximally united processes that reflect tabulation, rather than clustered individual processes. Dimensions: Holotype: $23 \times 28 \mu \mathrm{m}$. Range: length 20(23) $25 \mu \mathrm{m}$, breadth $23(24) 28 \mu \mathrm{m}$. Specimens measured 10.

Stratigraphic occurrence: latest Paleocene and earliest Eocene on the New Jersey Shelf (upper Vincetown and Manasquan formations, this paper), northern plain of the Gulf of Mexico (Alabama, Missisippi, personal observation), East Tasman Plateau (Ocean Drilling Program Leg 189, personal observation).

\subsection{List of encountered dinocyst species and complexes}

The generic allocation of taxa follows that cited in Fensome and Williams (2004) unless stated otherwise. Along with Florentinia reichartii sp. nov., some new taxa have been recorded and are discussed below, and will be formally described elsewhere. Notes on certain taxa are also provided. Illustrated taxa are followed by plate references in brackets. Achilleodinium biformoides (1A-B)
Achomosphaera alcicornum (1C)

Achomosphaera crassipellis

Adnatosphaeridium multispinosum

Adnatosphaeridium robustum (1D-F; 9A)

Alisocysta sp. 2 of Heilmann-Clausen (1985)

Apectodinium augustum (1I)

Apectodinium homomorphum Remarks: variation with very long processes abundant (1J; 9B-C)

Apectodinium parvum $(1 \mathrm{~K})$

Apectodinium quinquelatum Remarks: variation with very long processes abundant (1L)

Apteodinium spp.

Areoligera coronata

Areoligera senonensis

Areoligera complex. This complex includes the morphologically closely related, dorsal-ventrally compressed gonyaulacoid genera Areoligera, Glaphyrocysta and Adnatosphaeridium (9D)

Batiacasphaera compta

Batiacasphaera spp. (pars). Other species of Batiacasphaera Calligodinium aceras

Cerebrocysta spp. (9E)

Cerodinium denticulatum

Cerodinium depressum

Cerodinium speciosa

Cerodinium wardenense

Cladopyxidium saeptum (2A)

Cordosphaeridium fibrospinosum (2B-E; 9F-G)

Cordosphaeridium fibrospinosum complex. Several authors (e.g., Brinkhuis and Schiøler, 1996) have discussed the morphologically closely related genera Apteodinium, Cordosphaeridium, Damassadinium, Fibrocysta, Kenleya. Lanternosphaeridium, Muratodinium, Thalassiphora, and Turbiosphaera, and even others. The "plasticity" in specimens assignable to this group is extremely large and virtually any morphological intermediate between several types of genera may be readily identified in Late Palaeocene and Early Eocene assemblages. Following Brinkhuis and Schioler (1996), we have chosen C. fibrospinosum as a central taxon in this group. Ongoing studies (e.g., Houben, 2008), indicate that many of the morphological manifestations recorded within this complex may in fact represent a single biological species, yet with different morphological end-members through geological time.

Cordosphaeridium miminum

Cribroperidinium sp. A. An unusual, very large $(\sim 100 \mu \mathrm{m})$, thin-walled species of Cribroperidinium. Questionably assigned because the tabulation is only discernible at cingulum and through the 4" archeopyle; operculum detached. $(2 \mathrm{H})$ Cribroperidinium spp. (pars.). Other species of Cribroperidinium

Damassadinium spp. Part of the C. fibrospinosum complex

Dapsilidinium spp.

Deflandrea oebisfeldensis (2I)

Deflandrea phosphoritica 

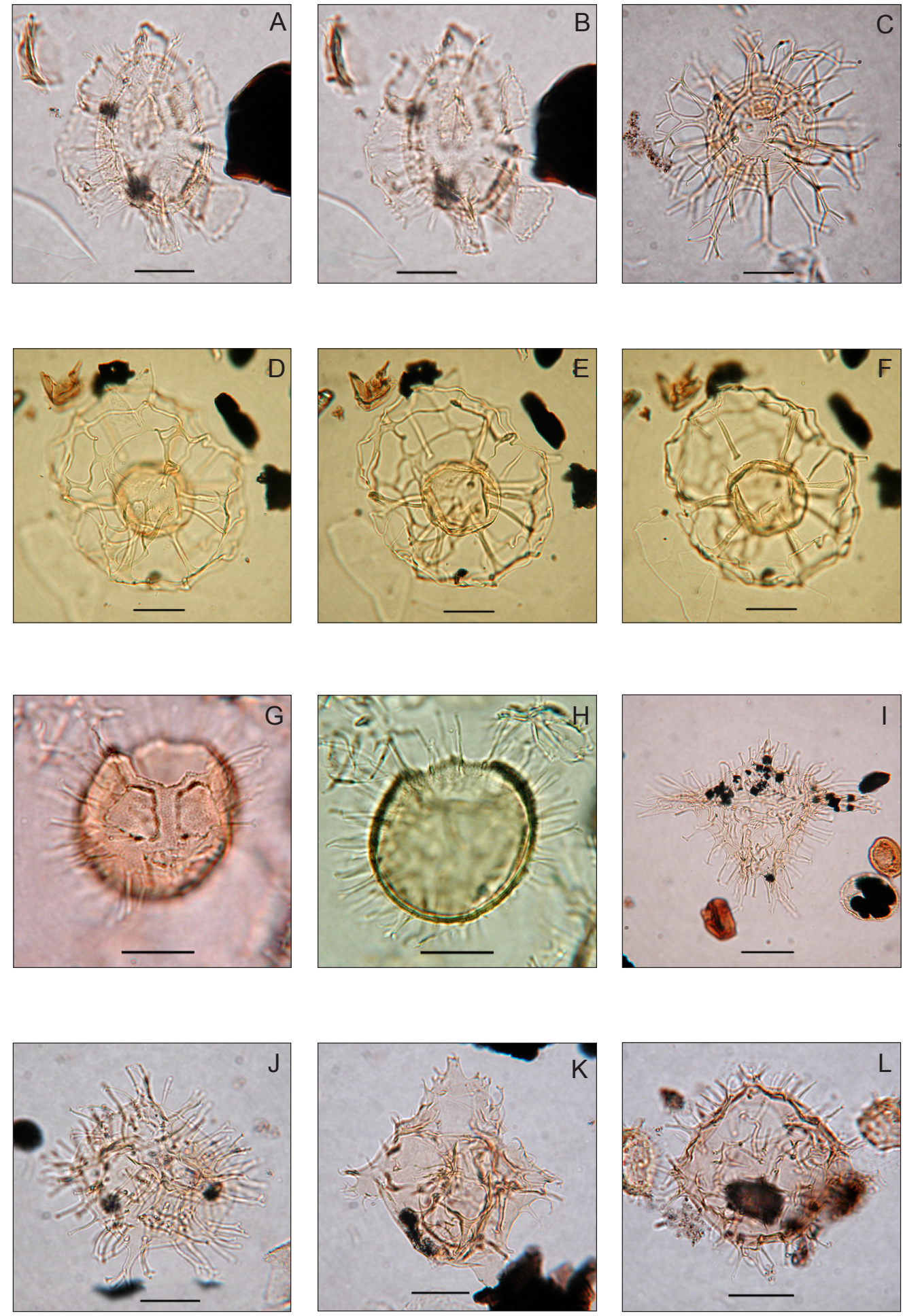

Plate 1. (A-B), Achilleodinium biformoides (Bass River, 357.76 mbs, \#1, England Finder coordinates: M61-2); (C), Achomosphaera alcicornu (Bass River, 360.20 mbs, \#1, P59-1); (D-F), Adnatosphaeridium robustum (Bass River, $358.12 \mathrm{mbs,} \mathrm{\# 1,} \mathrm{N56-2);} \mathrm{(G-H),} \mathrm{Alisocysta}$ sp. 2 of Heilmann-Clausen (1985) (Wilson Lake, 110.0 mbs, \#1, U45-1); (I), Apectodinium augustum (Wilson Lake, 107.40 mbs, \#1, O59-1); (J), Apectodinium homomorphum (Bass River, 353.25 mbs, \#1, L59-4); (K), Apectodinium parvum (Bass River, 354.41 mbs, \#1, N63-3); (L), Apectodinium quinquelatum (Wilson Lake, $91.51 \mathrm{mbs}$, \#1, M56-3). Scale bar=20 $\mu \mathrm{m}$. 

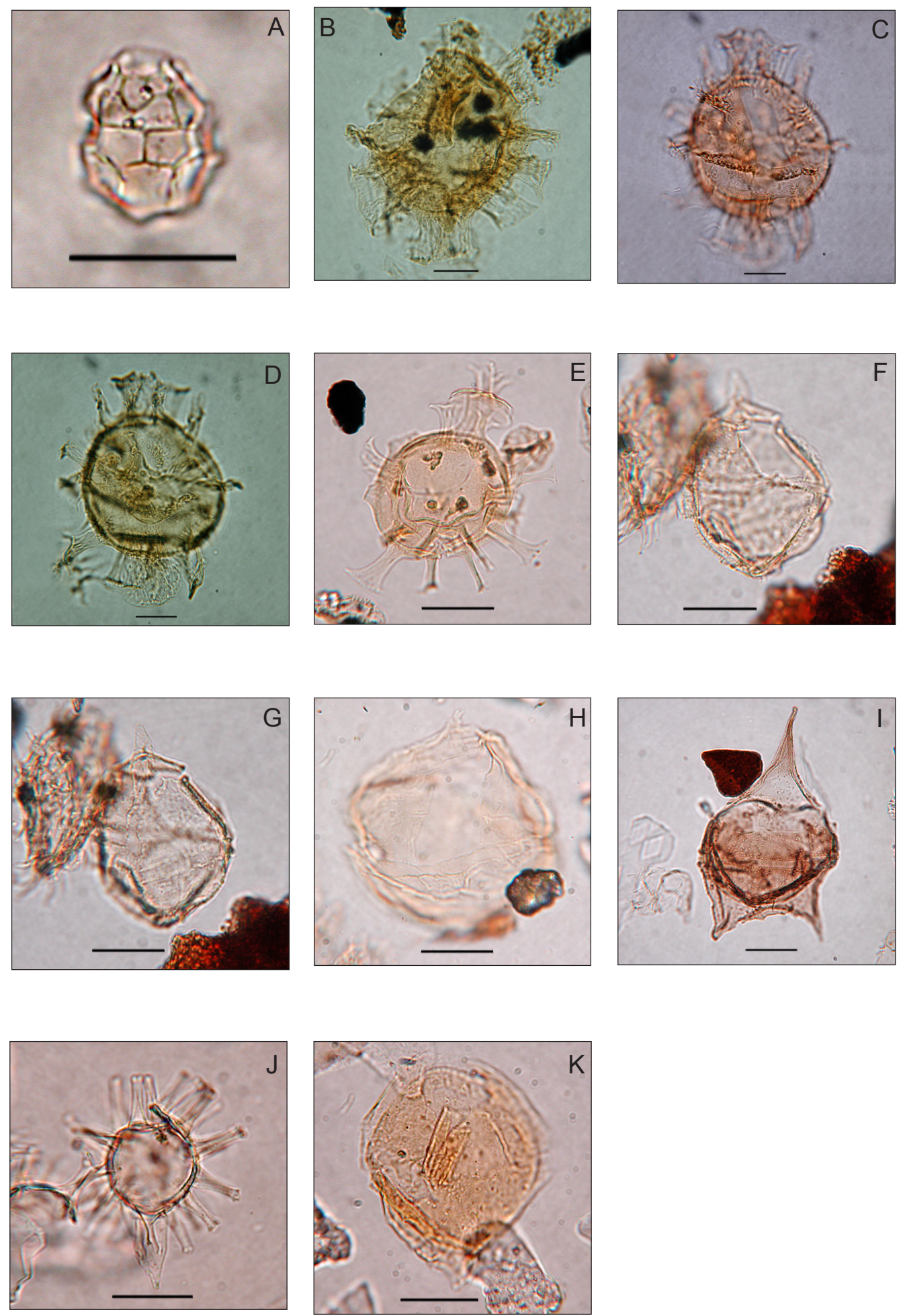

Plate 2. (A), Cladopyxidium saeptum (Wilson Lake, 112.76 mbs, \#1, England Finder coordinates: R44-3); (B), Cordosphaeridium fibrospinosum complex. Morphotype intermediate between C. fibrospinosum and Damassadinium spp. (Bass River, 366.20 mbs, \#1, L59-3); (C-D), Cordosphaeridium fibrospinosum complex. Morphotype intermediate between C. fibrospinosum and Turbiosphaera spp. (Bass River, 396.95 mbs, \#1, M62-1); (E), Cordosphaeridium fibrospinosum (Bass River, 356.69 mbs, \#1, M62-1); (F-G), Cribroperidinium spp. (Bass River, $357.30 \mathrm{mbs}$ \#1, Q52-1); (H), Cribroperidinium sp. A. (Bass River, 347.13 mbs, \#1, L64-2); (I), Deflandrea oebisfeldensis (Bass River, 374.19 mbs, \#1, H55-1); (J), Diphyes colligerum (Wilson Lake, 112.76 mbs, \#1, D53-3); (K), Dracodinium pachyderma (Bass River, $345.93 \mathrm{mbs}$, \#1, G60-4). Scale bar=20 $\mu \mathrm{m}$. 

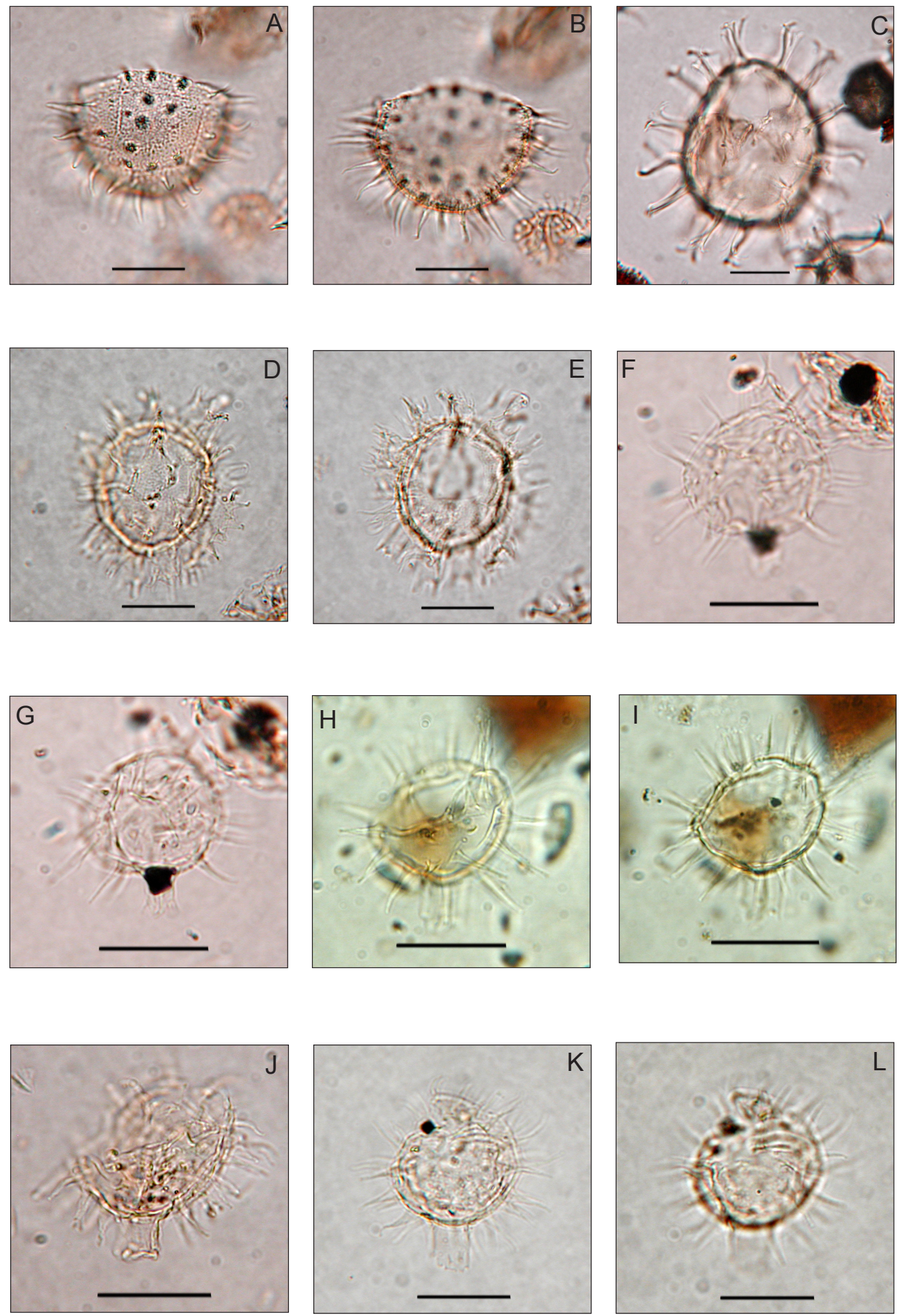

Plate 3. (A-B), Eocladopyxis peniculata (Wilson Lake, $112.76 \mathrm{mbs}$, England Finder coordinates: O48-3); (C), Fibrocysta spp. (Wilson Lake, 110.14 mbs, L45-2); (D-E), Florentinia ferox (Bass River, 357.76 mbs, L62-1); (F-L), Florentinia reichartii sp. nov. (F-G, paratype, Wilson Lake, 104.07 mbs, \#1, N56-1; H-I, paratype, Wilson Lake, 111.97 mbs, \#1, O57-1; J, paratype, Bass River, 349.04 mbs, \#1, L52-2; $\mathrm{K}-\mathrm{L}$, paratype, Bass River, $351.08 \mathrm{mbs}$, \#1, M49-2). Scale bar=20 $\mu \mathrm{m}$. 

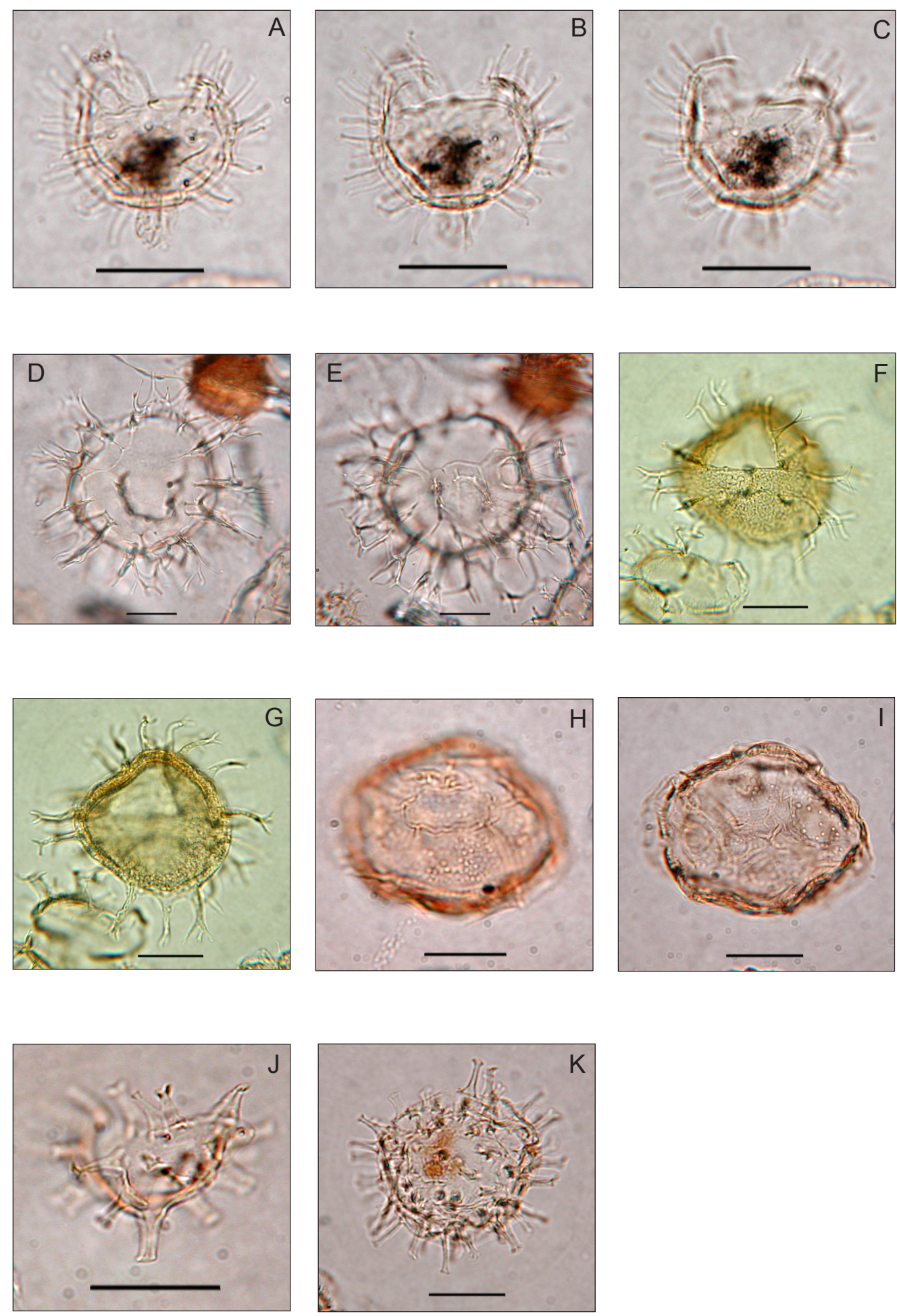

Plate 4. (A-C), Florentinia reichartii sp. nov. Holotype (Bass River, 355.26 mbs, \#1, England Finder coordinates: N52-2); (D-E), Glaphyrocysta volata (Wilson Lake, 112.76 mbs, \#1, M49-1); (F-G), Hafniasphaera septata (Wilson Lake, 110.14 mbs, \#2, L45-1); (H-I), Heteraulacacysta spp. (Wilson Lake, 110.73 mbs, \#1, M56-4); (J-K), Homotryblium spp. (J, Bass River, 349.44 mbs, \#1, K50-3; K, Bass River, $351.08 \mathrm{mbs}$, \#1, L49-3). Scale bar=20 $\mu \mathrm{m}$. 

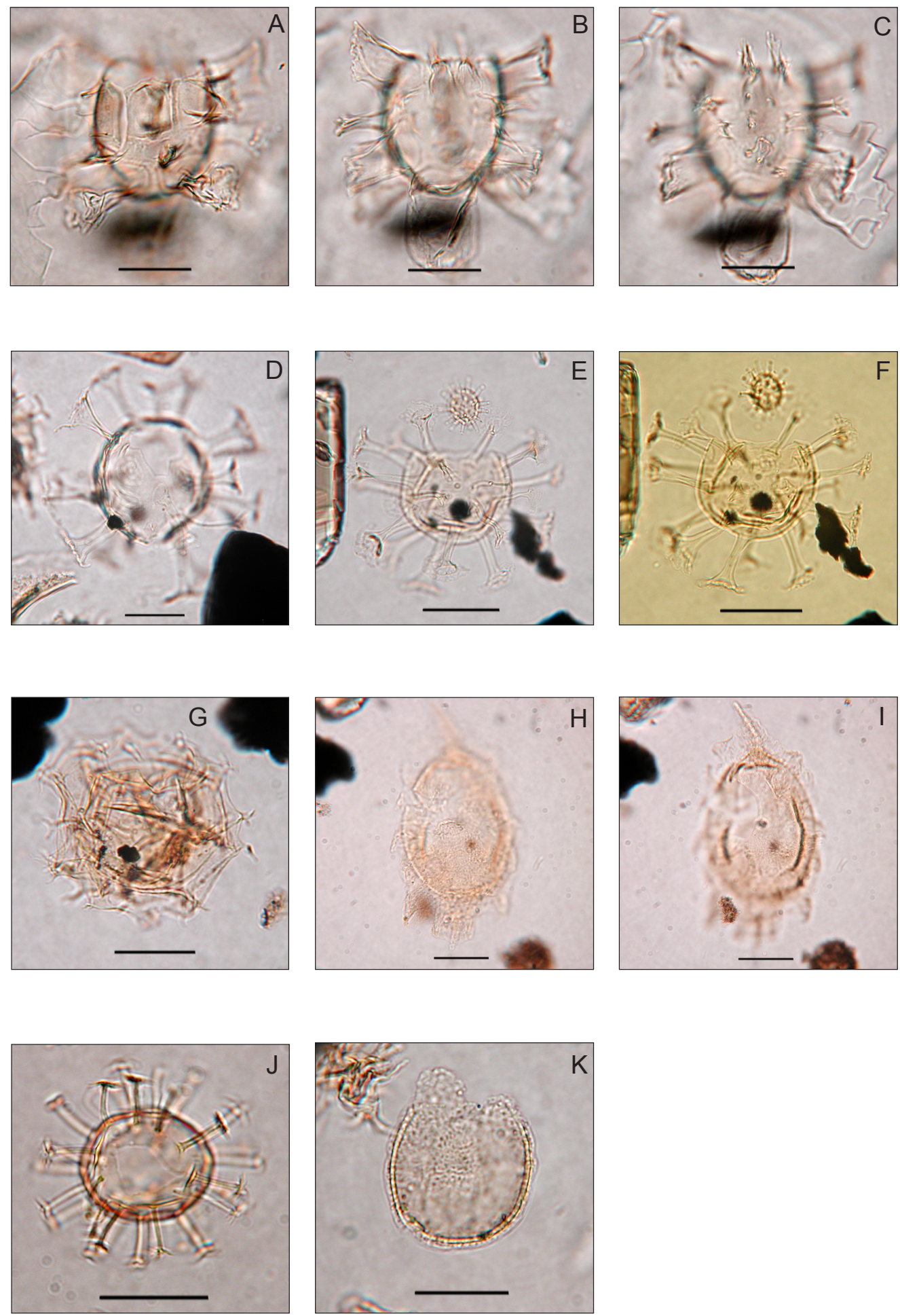

Plate 5. (A-C), Hystrichokolpoma salacia (Wilson Lake, $112.76 \mathrm{mbs}$, \#1, England Finder coordinates: O48-4); (D-F), Hystrichosphaeridium truswelliae (D, Wilson Lake, 110.14, \#1, G59-3; (E-F), Bass River, 357.76 mbs, \#1, O62-1); (G), Hystrichostrogylon spp. (Bass River, 356.69 mbs, \#1, M58-1); (H-I), Lanternosphaeridium lanosum (Bass River, 349.44 mbs, \#1, O53-3); (J), Melitasphaeridium pseudorecurvatum (Wilson Lake, 110.06 mbs, \#1, N52-1), (K), Membranosphaera spp. (Wilson Lake, 110.14 mbs, J53-4). Scale bar=20 $\mu$ m. 

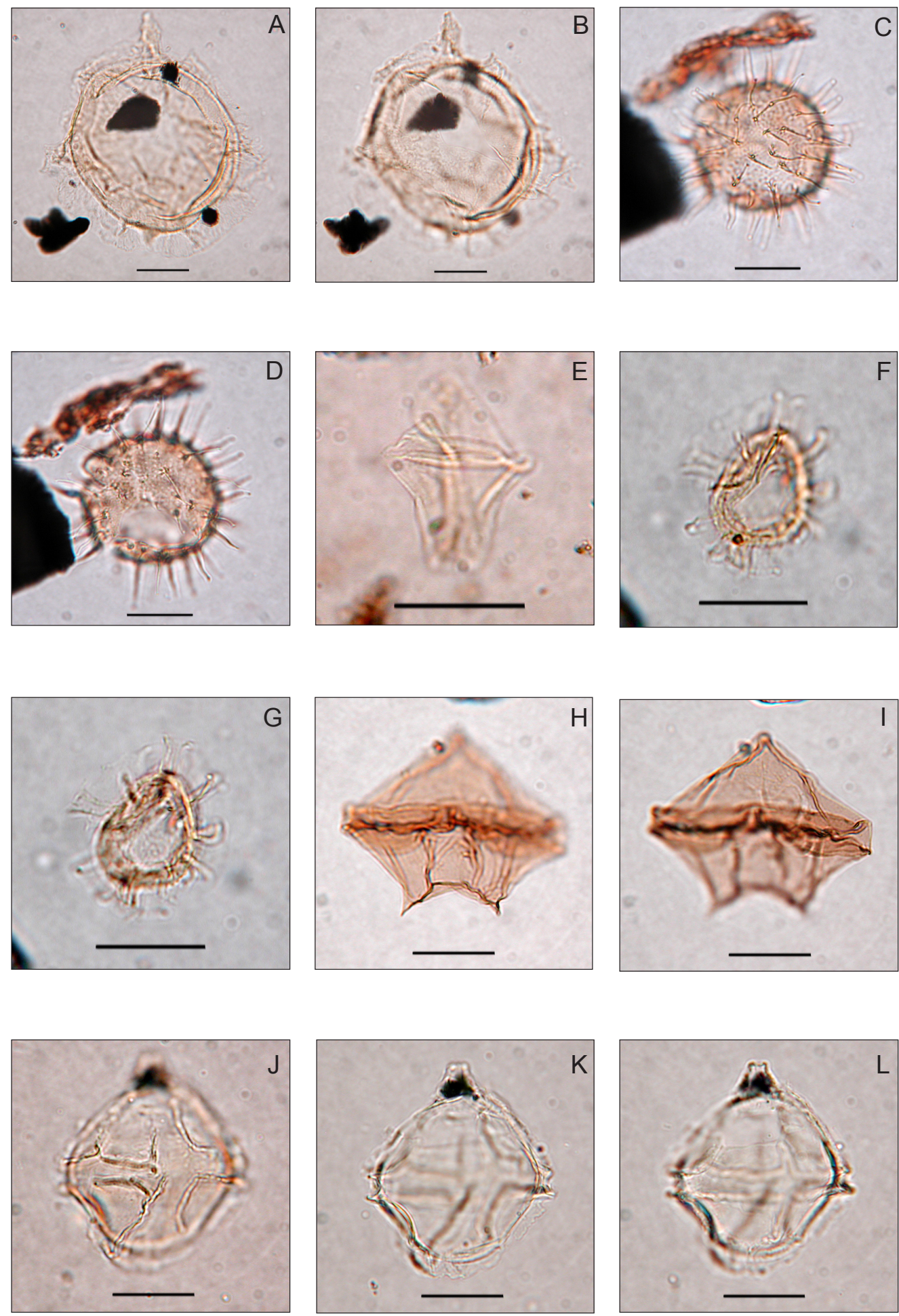

Plate 6. (A-B), Muratodinium fimbriatum (Bass River, $354.41 \mathrm{mbs,} \mathrm{\# 1,} \mathrm{England} \mathrm{Finder} \mathrm{coordinates:} \mathrm{N63-3);} \mathrm{(C-D),} \mathrm{Operculodinium} \mathrm{spp.}$ (Bass River, 359.77 mbs, \#1, N61-1); (E), Paleotetradinium minisculum (Wilson Lake, 111.97 mbs, \#1, N52-3); (F-G), Paucisphaeridium spp. (Bass River, 357.76 mbs, L56-4); (H-I), Phelodinium magnificum (Bass River, 356.69 mbs, \#1, S60-3); (J-L), Phthanoperidinium crenulatum (Wilson Lake, $95.96 \mathrm{mbs}$ \#1, J44-4). Scale bar=20 $\mu \mathrm{m}$. 

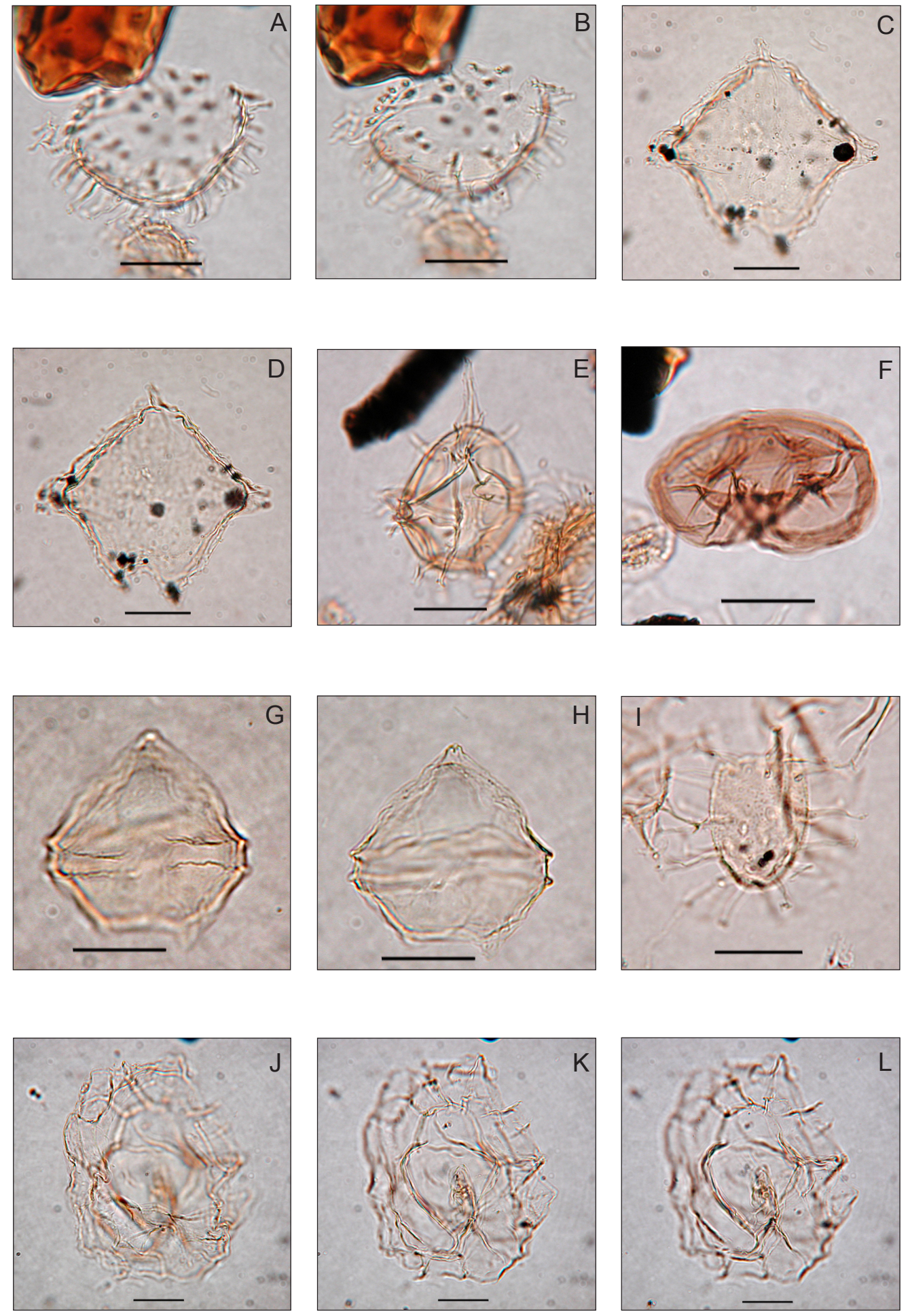

Plate 7. (A-B), Polysphaeridium zoharii (Bass River, 361.05 mbs, \#1, England Finder coordinates: N19-1); (C-D), Rhombodinium spp. (Wilson Lake, 109.42 mbs, \#1, L45-2); (E), Rottnestia borrusica (Bass River, 354.41 mbs, \#1, N58-4); (F), Selenopemphix nephroides (Bass River, 356.69 mbs, \#1, R61-4); (G-H), Senegalinium spp. (Wilson Lake, 94.40 mbs, \#1, T57-3); (I), Tanyosphaeridium spp. (Bass River, 350.66 mbs, \#1, N44-4); (J-L), Thalassiphora delicata (Bass River, 373.76 mbs, \#1, K60-2). Scale bar=20 $\mu \mathrm{m}$. 

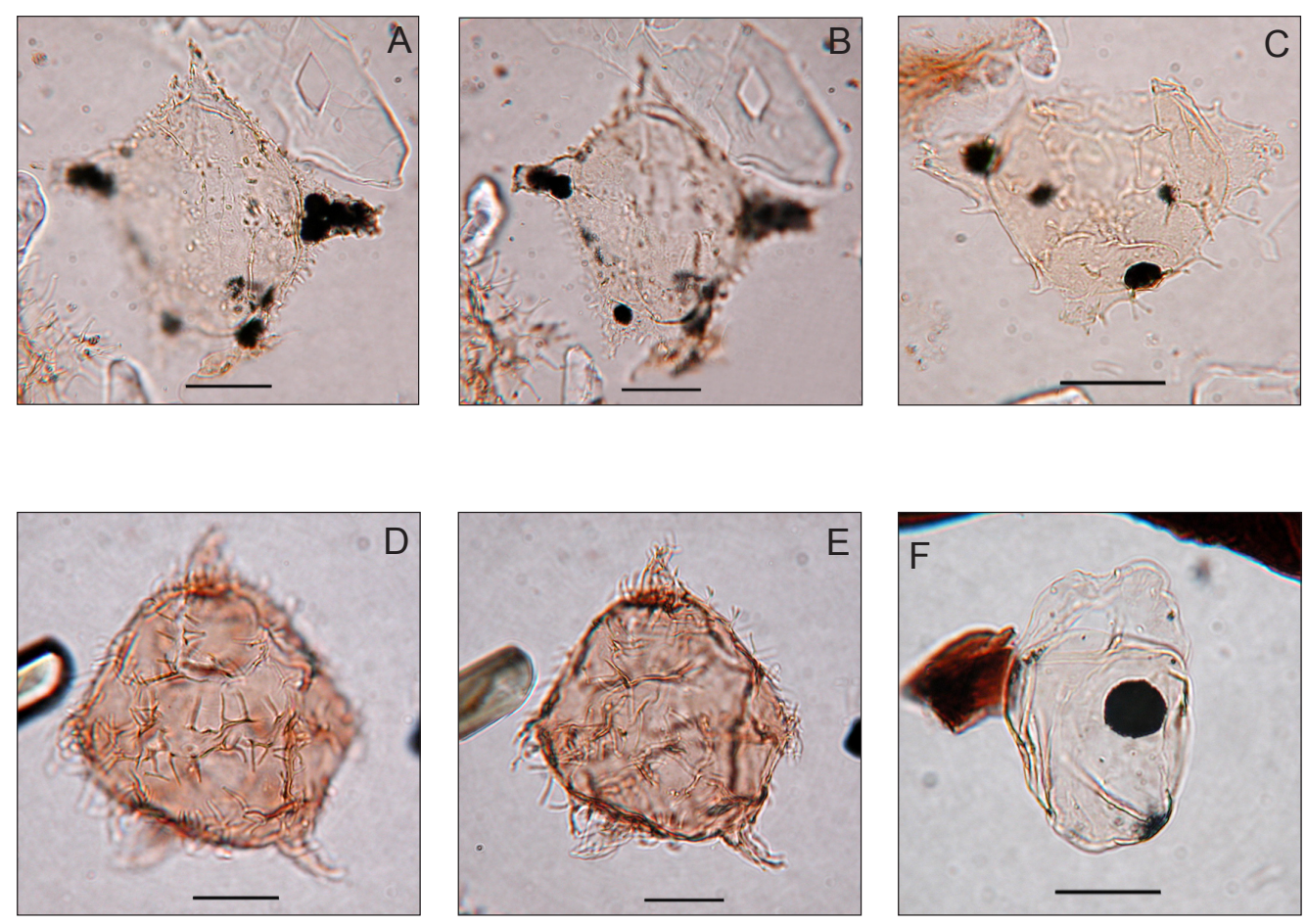

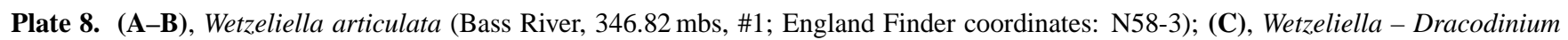
varielongitudum (Bass River, 345.96 mbs, \#1; L66-4); (D-E), Wilsonidium tesselatum (Bass River, 357.39 mbs, \#1, J54-4); (F), Nelsoniella spp. (potentially reworked; Bass River, $366.93 \mathrm{mbs}$, \#1, M60-3). Scale bar=20 $\mu \mathrm{m}$.

Diphyes colligerum $(2 \mathrm{~J} ; 9 \mathrm{H})$

Dracodinium pachydermum (2K)

Dracodinium varielongitudum (8C)

Eocladopyxis peniculata (3A-B; 9I-L)

Eocladopyxis? sp. A. A proximate goniodomid, questionably assigned to Eocladopyxis

Fibrocysta axialis (10A) Part of the C. fibrospinosum complex

Fibrocysta bipolaris Part of the C. fibrospinosum complex

Fibrocysta sp. A. A species of Fibrocysta with numerous slender processes. Part of the C. fibrospinosum complex

Fibrocysta spp. (pars). All other taxa assignable to Fibrocysta (3C) Part of the $C$. fibrospinosum complex

Florentinia ferox (3D-E)

Florentinia reichartii sp. nov. (3D-L; 4A-C; 10B-E)

Glaphyrocysta ordinata

Glaphyrocysta pastielsii/exuberans

Glaphyrocysta reticulata

Glaphyrocysta volata (3D-E; 10F-G)

Hafniasphaera septata $(3 \mathrm{~F}-\mathrm{G})$

Heteraulacacysta spp. (3H-I)

Homotryblium spp. (3J-K)

Horologiniella spp.

Hystrichokolpoma salacia (5A-C)

Hystrichokolpoma spp. (pars)
Hystrichosphaeridium truswelliae Remarks: first record outside Southern Ocean. (5D-F; 10H-I)

Hystrichosphaeridium tubiferum

Hystrichostrogylon spp. (5G)

Impagidinium californiense

Impagidinium sp. cf. I. sp. B Crouch and Hollis (1996)

Impagidinium sp. cf. sphaericum

Impagidinium spp. (pars)

Kallosphaeridium brevibarbatum

Kenleya spp.

Lanternosphaeridium lanosum (5H-I; 10J). Part of the $C$. $f$ brospinosum complex

Lejeunecysta spp.

Leptodinium spp.

Lingulodinium machaerophorum

Melitasphaeridium pseudorecurvatum

Membranosphaera spp. Remarks: tabulation sometimes discernable in the distribution of process ornamentation $(5 \mathrm{~K}$; $10 \mathrm{~K})$

Microdinium ornatum

Muratodinium fimbriatum (6A-B; 10L). Part of the C. fibrospinosum complex

Nelsoniella (potentially reworked; $8 \mathrm{~F}$ )

Nematosphaeropsis spp.

Operculodinium severinii

Operculodinium cf. O. israelianum. 

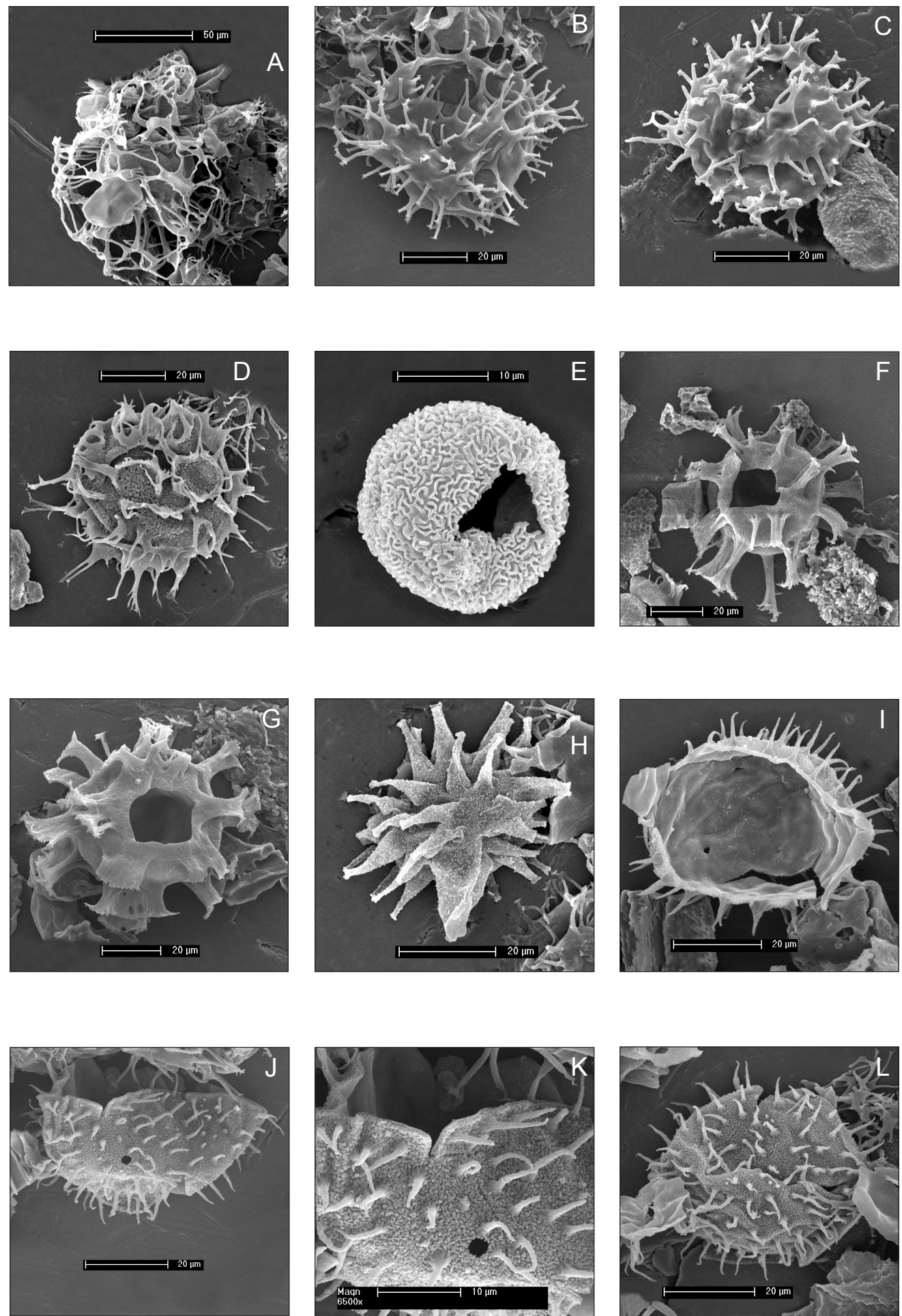

Plate 9. (A), Adnatosphaeridium robustum (Bass River, 364.89 mbs); (B-C), Apectodinium homomorphum (Bass River, 357.39 mbs); (D), Areoligera spp. (Bass River, $355.93 \mathrm{mbs}$ ); (E), Cerebrocysta spp. (Bass River, $355.93 \mathrm{mbs}$ ); (F-G), Cordosphaeridium fibrospinosum (F, Bass River 356.93 mbs; (G), Bass River, 355.93 mbs); (H), Diphyes colligerum (Bass River, 357.39 mbs); (I-L), Eocladopyxis peniculata (Bass River, $364.89 \mathrm{mbs}$; $(\mathrm{K})$ is a detail of $(\mathrm{J})$ to indicate sutures). 

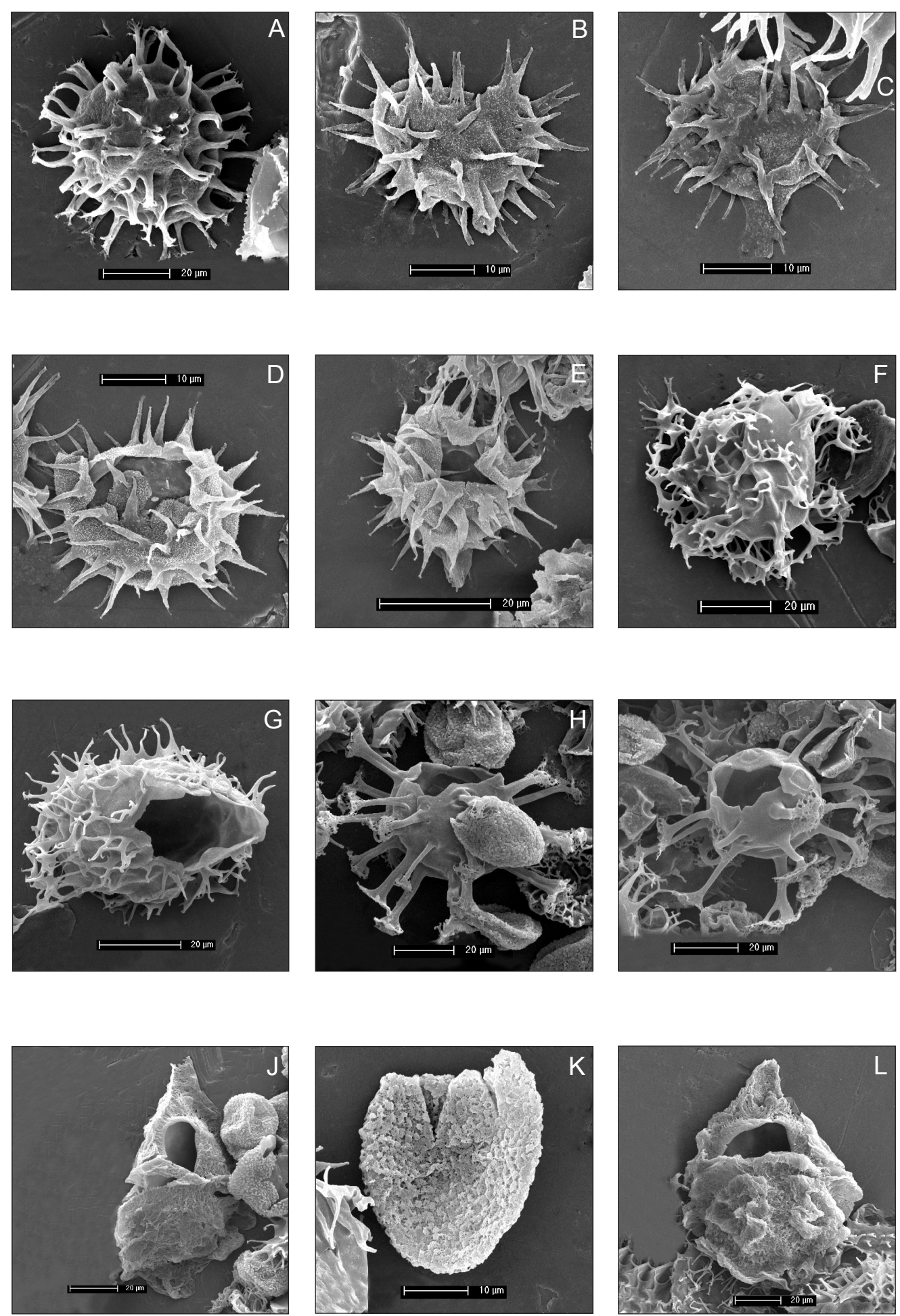

Plate 10. (A), Fibrocysta axialis (Bass River, $356.93 \mathrm{mbs);} \mathrm{(B-E),} \mathrm{Florentinia} \mathrm{reichartii} \mathrm{sp.} \mathrm{nov.} \mathrm{(B-D,} \mathrm{Bass} \mathrm{River,} 356.93$; (E), 355.93 mbs); (F-G), Glaphyrocysta volata (Bass River, $364.89 \mathrm{mbs);(H-I),} \mathrm{Hystrichosphaeridium} \mathrm{truswelliae} \mathrm{(Bass} \mathrm{River,} 357.39 \mathrm{mbs})$; (J), Lanternosphaeridium lanosum (Bass River, $357.39 \mathrm{mbs}$ ); (K), Membranosphaera spp. (Bass River 357.39 mbs); (L), Muratodinium fimbriatum (Bass River, 357.39 mbs). 

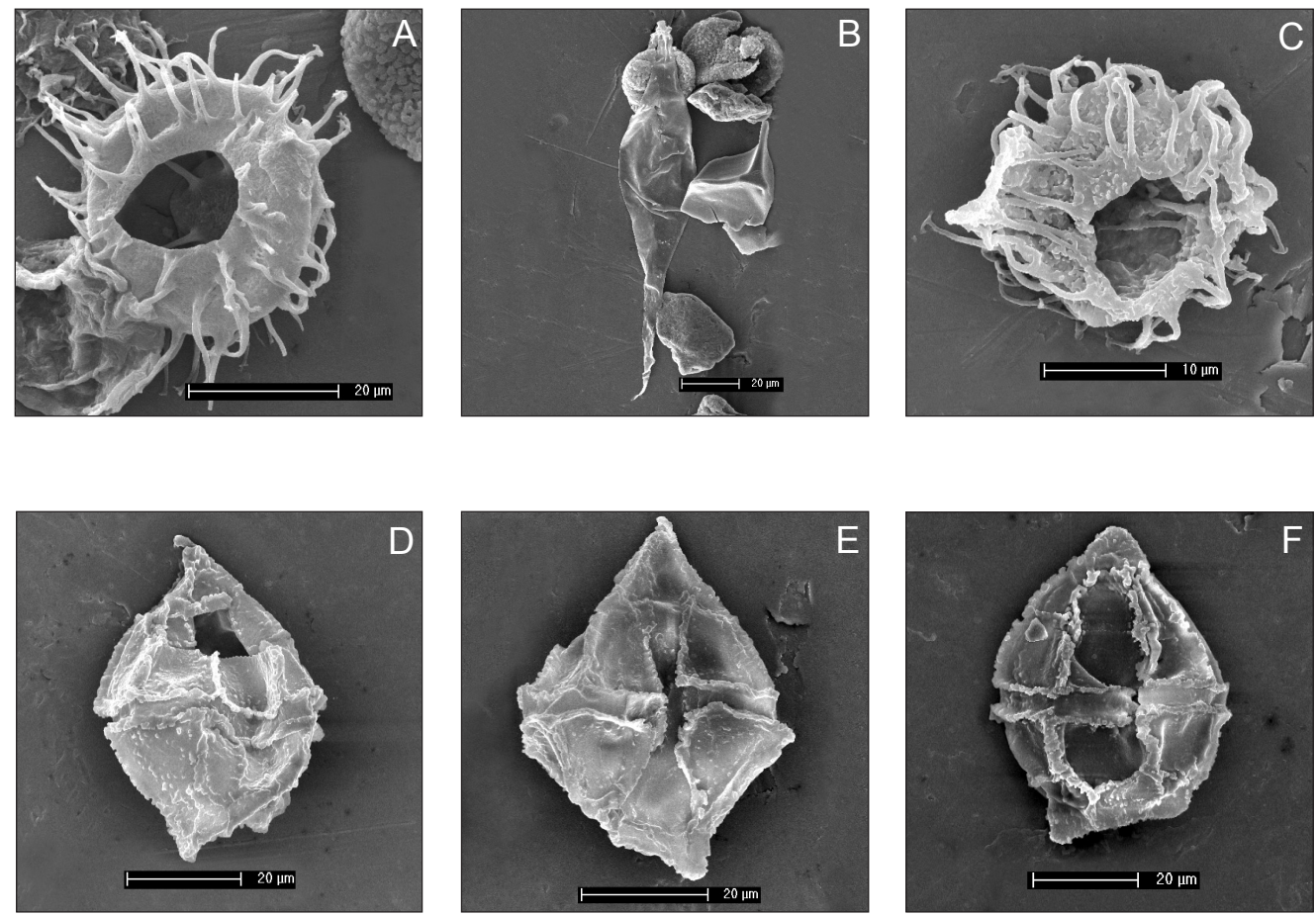

Plate 11. (A), Operculodinium spp. (Bass River, 357.39 mbs); (B), Palaeocystodinium spp. (Bass River, 357.39 mbs); (C), Paucisphaeridium spp. (Bass River 364.89 mbs); (D-F), Phthanoperidinium crenulatum (Bass River 356.93 mbs).

Operculodinium spp. (pars) (6C-D; 11A)

Paleocystodinium lidiae

Paleocystodinium spp (pars) (11B)

Paleotetradinium minisculum (6E)

Paucisphaeridium inversibuccinum

Paucisphaeridium spp. (pars) (6F-G; 11C)

Phelodinium magnificum (6H-I)

Phthanoperidinium crenulatum (6J-L; 11D-F)

Phthanoperidium spp. (pars)

Polysphaeridium zoharyi (7A-B)

Rhombodinium spp. (7C-D)

Rottnestia borussica (7E)

Selenopemphix nephroides (7F)

Senegalinium spp. (7G-H)

Senegalinium complex. Includes all peridinioid taxa with a 6-sided second intercalary plate; here comprising Alterbidinium spp., Cerodinium spp., Deflandrea spp., Phthanoperidinium spp., and Senegalinium spp.

Spiniferites pseudofurcatus

Spiniferites ramosus

Spiniferites spp. (pars)

Tanyosphaeridium spp. (7I)

Thalassiphora delicata (7J-L)

Thalassiphora pelagica. Part of the C. fibrospinosum complex

Turbiosphaera spp. Part of the C. fibrospinosum complex Wetzeliella articulata (8A-B)
Wetzeliella meckelfeldensis

Wilsonidium tesselatum (8D-E)

Acknowledgements. This research used samples and data provided by the Ocean Drilling Program (ODP; now Integrated Ocean Drilling Program: IODP). Funding for this research was provided by the Netherlands Organisation for Scientific Research to AS (NWO-VENI grant \#863.07.001), the Utrecht Biogeology Center and the LPP Foundation. We thank Jim Browning, Ken Miller (both Rutgers University), John Firth and Gar Esmay (both IODP) for help regarding the logistics around sampling the Bass River section, and Samantha Gibbs (NOC, Southampton), Ellen Thomas (Yale) and James Zachos (UC Santa Cruz) for providing samples from the Wilson Lake section. We thank Jim Riding and two anonymous reviewers for their comments, which significantly improved the paper. We thank Andy Lotter (Utrecht University) for advice regarding PCA and CCA analyses and Urbino Summer School in Paleoclimatology (USSP) instructors and students and Peter Lippert (UC Santa Cruz) for discussions. Leonard Bik, Jan van Tongeren and Natasja Welters are thanked for technical support.

Edited by: V. Brovkin

\section{References}

Abdul Aziz, H., Hilgen, F. J., van Luijk, G. M., Sluijs, A., Kraus, M. J., Pares, J. M., and Gingerich, P. D.: Astronomical climate control on paleosol stacking patterns in the upper Paleocene - 
lower Eocene Willwood Formation, Bighorn Basin, Wyoming, Geology, 36, 531-534; doi:510.1130/G24734A.24731, 2008.

Archer, D.: Fate of fossil fuel $\mathrm{CO}_{2}$ in geologic time, J. Geophys. Res., 110, C09S05, doi:10.1029/2004JC002625, 2005.

Archer, D., Eby, M., Brovkin, V., Ridgwell, A., Cao, L., Mikolajewicz, U., Caldeira, K., Matsumoto, K., Munhoven, G., Montenegro, A., and Tokos, K.: Atmospheric Lifetime of Fossil Fuel Carbon Dioxide, Annu. Rev. Earth Pl. Sc., 37, 117-134, doi:10.1146/annurev.earth.031208.100206, 2009.

Bowen, G. J., Beerling, D. J., Koch, P. L., Zachos, J. C., and Quattlebaum, T.: A humid climate state during the Palaeocene/Eocene thermal maximum, Nature, 432, 495-499, 2004.

Bowen, G. J., Bralower, T. J., Delaney, M. L., Dickens, G. R., Kelly, D. C., Koch, P. L., Kump, L. R., Meng, J., Sloan, L. C., Thomas, E., Wing, S. L., and Zachos, J. C.: Eocene Hyperthermal Event Offers Insight Into Greenhouse Warming, EOS, Transactions, American Geophysical Union, 87, 165, 169, 2006.

Bradford, M. R. and Wall, D. A.: The Distribution of Recent Organic-Walled Dinoflagellate Cysts in the Persian Gulf, Gulf of Oman, and northwestern Arabian Sea, Palaeontographica, 192, 16-84, 1984.

Brinkhuis, H.: Late Eocene to Early Oligocene dinoflagellate cysts from the Priabonian type-area (Northeast Italy); biostratigraphy and palaeoenvironmental interpretation, Palaeogeogr. Palaeocl., 107, 121-163, 1994.

Brinkhuis, H., Romein, A. J. T., Smit, J., and Zachariasse, W. J.: Danian-Selandian dinoflagellate cysts from lower latitudes with special reference to the El Kef section, NW Tunesia, Geologiska Föreningens i Stockholm Förhandlingar (GFF; Transactions of the Geological Society in Stockholm), 116, 46-48, 1994.

Brinkhuis, H. and Schiøler, P.: Palynology of the Geulhemmerberg Cretaceous/Tertiary boundary section (Limburg, SE Netherlands), Geologie en Mijnbouw, 75, 193-213, 1996.

Brinkhuis, H., Sengers, S., Sluijs, A., Warnaar, J., and Williams, G. L.: Latest Cretaceous to earliest Oligocene, and Quaternary dinoflagellate cysts from ODP Site 1172, East Tasman Plateau, in: Proceedings Ocean Drilling Program, Scientific Results, edited by: Exon, N. F., Kennett, J. P., and Malone, M., online available at: http://www-odp.tamu.edu/publications/ 189_SR/106/106.htm, College Station, Texas, 1-48, 2003.

Brinkhuis, H., Schouten, S., Collinson, M. E., Sluijs, A., Sinninghe Damsté, J. S., Dickens, G. R., Huber, M., Cronin, T. M., Onodera, J., Takahashi, K., Bujak, J. P., Stein, R., van der Burgh, J., Eldrett, J. S., Harding, I. C., Lotter, A. F., Sangiorgi, F., van Konijnenburg-van Cittert, H., de Leeuw, J. W., Matthiessen, J., Backman, J., Moran, K., and the Expedition 302 Scientists: Episodic fresh surface waters in the Eocene Arctic Ocean, Nature, 441, 606-609, 2006.

Bujak, J. P. and Brinkhuis, H.: Global warming and dinocyst changes across the Paleocene/Eocene Epoch boundary, in: Late Paleocene - early Eocene climatic and biotic events in the marine and terrestrial records, edited by: Aubry, M.-P., Lucas, S. G., and Berggren, W. A., Columbia University Press, New York, 277-295, 1998.

Buskey, E. J.: Behavioral components of feeding selectivity of the heterotrophic dineflagellate Protoperidinium pellucidum, Mar. Ecol. Prog. Ser., 153, 77-89, 1997.

Bütschli, O.: Protozoa, in: Klassen und Ordnungen des ThierReichs, Wissenschaftlich Dargestellt in Wort und Bild, edited by:
Bronn, H. G., Wintersche Verlagsbuchhandling, Leibzig, 8651088, 1885.

Canfield, D. E. and Berner, R. A.: Dissolution and pyritization of magnetite in anoxie marine sediments Geochim. Cosmochim.Ac., 51, 645-659, 1987.

Cramer, B. S., Aubry, M.-P., Miller, K. G., Olsson, R. K., Wright, J. D., and Kent, D. V.: An exceptional chronologic, isotopic, and clay mineralogic record of the latest Paleocene thermal maximum, Bass River, NJ, ODP 174AX, Bulletin de la Société Géologique de France, 170, 883-897, 1999.

Crouch, E. M. and Hollis, C. J.: Paleogene palynomorph and radiolarian biostratigraphy of DSDP Leg 29, Sites 280 and 281 South Tasman Rise, 1996.

Crouch, E. M., Heilmann-Clausen, C., Brinkhuis, H., Morgans, H. E. G., Rogers, K. M., Egger, H., and Schmitz, B.: Global dinoflagellate event associated with the late Paleocene thermal maximum, Geology, 29, 315-318, 2001.

Crouch, E. M., Brinkhuis, H., Visscher, H., Adatte, T., and Bolle, M.-P.: Late Paleocene- early Eocene dinoflagellate cyst records from the Tethys: Further observations on the global distribution of Apectodinium, in: Causes and Consequences of Globally Warm Climates in the Early Paleogene. Geological Society of America Special Paper 369, edited by: Wing, S. L., Gingerich, P. D., Schmitz, B., and Thomas, E., Geological Society of America, Boulder, Colorado, 113-131, 2003a.

Crouch, E. M., Dickens, G. R., Brinkhuis, H., Aubry, M.-P., Hollis, C. J., Rogers, K. M., and Visscher, H.: The Apectodinium acme and terrestrial discharge during the Paleocene-Eocene thermal maximum: new palynological, geochemical and calcareous nannoplankton observations at Tawanui, New Zealand, Palaeogeogr. Palaeocl., 194, 387-403, 2003 b.

Crouch, E. M. and Brinkhuis, H.: Environmental change across the Paleocene-Eocene transition from eastern New Zealand: A marine palynological approach, Mar. Micropaleontol., 56, 138-160, 2005.

Dale, B. and Fjellså, A.: Dinoflagellate cysts as paleoproductivity indicators: State of the art, potential and limits, in: Carbon Cycling in the Glacial Ocean: Constraints on the Ocean's Role in Global Change, edited by: Zahn, R., Pedersen, T. F., Kaminski, M. A., and Labeyrie, L., Springer, Berlin, 521-537, 1994.

Dale, B.: The sedimentary record of dinoflagellate cysts: looking back into the future of phytoplankton blooms, Sci. Mar., 65, 257272, 2001.

Dale, B., Dale, A. L., and Prince, I.: Statistical modelling of ecological signals: a new method for biostratigraphy, in: Recent Developments in Applied Biostratigraphy, edited by: Powell, A. J. and Riding, J. B., The Micropalaeontological Society, Special Publications, London, UK, 179-203, 2005.

Dickens, G. R., O’Neil, J. R., Rea, D. K., and Owen, R. M.: Dissociation of oceanic methane hydrate as a cause of the carbon isotope excursion at the end of the Paleocene, Paleoceanography, 10, 965-971, 1995.

Dickens, G. R., Castillo, M. M., and Walker, J. C. G.: A blast of gas in the latest Paleocene: Simulating first-order effects of massive dissociation of oceanic methane hydrate, Geology, 25, 259-262, 1997.

Dickens, G. R.: The riddle of the clays, Nature Geoscience, 1, 8688, 2008.

Diffenbaugh, N. S., Giorgi, F., and Pal, J. S.: Climate change 
hotspots in the United States, Geophys. Res. Lett., 35, L16709, doi:10.1029/2008GL035075, 2008.

Egger, H., Fenner, J., Heilmann-Clausen, C., Rögl, F., Sachsenhofer, R., and Schmitz, B.: Paleoproductivity of the northwestern Tethyan margin (Anthering section, Austria) across the Paleocene-Eocene transition, in: Causes and Consequences of Globally Warm Climates in the Early Paleogene, Geological Society of America Special Paper 369, edited by: Wing, S. L., Gingerich, P. D., Schmitz, B., and Thomas, E., Geological Society of America, Bolder, Colorado, 133-146, 2003.

Ellegaard, M.: Variations in dinoflagellate cyst morphology under conditions of changing salinity during the last 2000 years, Rev. Palaeobot. Palyno., 109, 65-81, 2000.

Emanuel, K., DesAutels, C., Holloway, C., and Korty, R.: Environmental Control of Tropical Cyclone Intensity, J. Atmos. Sci., 61, 843-858, 2004.

Emanuel, K.: Increasing destructiveness of tropical cyclones over the past 30 years, Nature, 436, 686-688, 2005.

Evitt, W. R.: Sporopollenin dinoflagellate cysts: their morphology and interpretation, American Association of Stratigraphic Palynologists Foundation, Dallas, USA, 1985.

Fensome, R. A., Taylor, F. J. R., Norris, G., Sarjeant, W. A. S., Wharton, D. I., and Williams, G. L.: A Classification of Fossil and Living Dinoflagellates, Micropaleontology, Special Publication, 351 pp., 1993.

Fensome, R. A., Gocht, H., and Williams, G. L.: The Eisenack Catalog of Fossil Dinoflagellates. New Series. Volume 4, E. Schweizerbart'sche Verlagsbuchhandlung, Stuttgart, Germany, 2009-2548, 1996a.

Fensome, R. A., Riding, J. B., and Taylor, F. J. R.: Chapter 6. Dinoflagellates, in: Palynology: principles and appliocations, edited by: Jansonius, J. and McGregor, D. C., American Association of Stratigraphic Palynologists Foundation, 107-169, 1996b.

Fensome, R. A. and Williams, G. L.: The Lentin and Williams Index of Fossil Dinoflagellates 2004 Edition, American Association of Stratigraphic Palynologists (AASP) Contribution Series 42, 909 pp., 2004.

Firth, J. V.: Upper Middle Eocene to Oligocene dinoflagellate biostratigraphy and assemblage variations in hole 913B, Greenland Sea, in: Proceedings of the Ocean Drilling Program, Scientific Results, edited by: Thiede, J., Myrhe, A. M., Firth, J. V., Johnson, G. L., and Ruddiman, W. F., Texas A \& M University, Ocean Drilling Program, College Station, TX, United States, College Station, Texas, 203-242, 1996.

Gavrilov, Y., Shcherbinina, E. A., and Oberhänsli, H.: PaleoceneEocene boundary events in the northeastern Peri-Tethys, in: Causes and Consequences of Globally Warm Climates in the Early Paleogene. Geological Society of America Special Paper 369, edited by: Wing, S. L., Gingerich, P. D., Schmitz, B., and Thomas, E., Geological Society of America, Bolder, Colorado, 147-168, 2003.

Gibbs, S. J., Bralower, T. J., Bown, P. R., Zachos, J. C., and Bybell, L. M.: Shelf and open-ocean calcareous phytoplankton assemblages across the Paleocene-Eocene Thermal Maximum: Implications for global productivity gradients, Geology, 34, 233-236, 2006.

Gibson, T. G., Bybell, L. M., and Owens, J. P.: Latest Paleocene lithologic and biotic events in neritic deposits of Southwestern New Jersey, Paleoceanography, 8, 495-514, 1993.
Gibson, T. G., Bybell, L. M., and Mason, D. B.: Stratigraphic and climatic implications of clay mineral changes around the Paleocene/Eocene boundary of the northeastern US margin, Sediment. Geol., 134, 65-92, 2000.

Giusberti, L., Rio, D., Agnini, C., Backman, J., Fornaciari, E., Tateo, F., and Oddone, M.: Mode and tempo of the PaleoceneEocene thermal maximum in an expanded section from the Venetian pre-Alps, Geological Society of America Bulletin, 119, 391412, 2007.

Hallett, R. I.: Consequences of Environmental Change on the Growth and Morphology of Lingulodinium polyedrum (Dinophyceae) in Culture, Ph.D., University of Westminster, London, 109 pp., 1999.

Harrington, G. J.: Geographic patterns in the floral response to Paleocene-Eocene warming, in: Causes and Consequences of Globally Warm Climates in the Early Paleogene, edited by: Wing, S. L., Gingerich, P. D., Schmitz, B., and Thomas, E., Geological Society of America Special Paper 369, Boulder, Colorado, 381-393, 2003.

Heilmann-Clausen, C.: Dinoflagellate stratigraphy of the Uppermost Danian to Ypresian in the Viborg 1 borehole, Central Jylland, Denmark, DGU A7, 1-69, 1985.

Heilmann-Clausen, C. and Egger, H.: The Anthering outcrop (Austria), a key-section for correlation between Tethys and Northwestern Europe near the Paleocene/Eocene boundary, in: Early Paleogene Warm Climates and Biosphere Dynamics, edited by: Schmitz, B., Sundquist, B., and Andreasson, F. P., GFF (Geologiska Föreningens Förhandlingar), Geological Society of Sweden, Uppsala, p. 69, 2000.

Higgins, J. A. and Schrag, D. P.: Beyond methane: Towards a theory for the Paleocene-Eocene Thermal Maximum, Earth Planet. Sci. Lett., 245, 523-537, 2006.

Hollis, C. J., Dickens, G. R., Field, B. D., Jones, C. M., and Percy Strong, C.: The Paleocene-Eocene transition at Mead Stream, New Zealand: a southern Pacific record of early Cenozoic global change, Palaeogeogr. Palaeocl., 215, 313-343, 2005.

Houben, S.: Organic Walled Dinoflagellate Cysts as indicators for environmental change during the Middle Eocene Climatic Optimum (MECO): results from ODP Leg 120, Site 748 (Kerguelen Plateau), M.Sc, Palaeoecology; Institute of Environmental Biology, Utrecht University, Utrecht, 29 pp., 2008.

Iakovleva, A. I., Brinkhuis, H., and Cavagnetto, C.: Late Palaeocene-Early Eocene dinoflagellate cysts from the Turgay Strait, Kazakhstan; correlations across ancient seaways, Palaeogeogr. Palaeocl., 172, 243-268, 2001.

John, C. M., Bohaty, S. M., Zachos, J. C., Sluijs, A., Gibbs, S. J., Brinkhuis, H., and Bralower, T. J.: North American continental margin records of the Paleocene-Eocene thermal maximum: Implications for global carbon and hydrological cycling, Paleoceanography, 23, PA2217, doi:2210.1029/2007PA001465, 2008.

Kennett, J. P. and Stott, L. D.: Abrupt deep-sea warming, palaeoceanographic changes and benthic extinctions at the end of the Palaeocene, Nature, 353, 225-229, 1991.

Koch, P. L., Zachos, J. C., and Gingerich, P. D.: Correlation between isotope records in marine and continental carbon reservoirs near the Palaeocene/Eocene boundary, Nature, 358, 319322, 1992.

Kopp, R. E., Raub, T. D., Schumann, D., Vali, H., Smirnov, A. V., and Kirschvink, J. L.: Magnetofossil spike during the 
Paleocene-Eocene thermal maximum: Ferromagnetic resonance, rock magnetic, and electron microscopy evidence from Ancora, New Jersey, United States, Paleoceanography, 22, PA4103, doi:10.1029/2007PA001473, 2007.

Kraus, M. J. and Riggins, S.: Transient drying during the Paleocene-Eocene Thermal Maximum (PETM): Analysis of paleosols in the bighorn basin, Wyoming, Palaeogeogr. Palaeocl., 245, 444-461, 2007.

Lentin, J. K. and Vozzhennikova, T. F.: The fossil dinoflagellate cysts Kisselovia emend. and Charlesdowniea gen. nov., Rev. Palaeobot. Palyno., 58, 215-229, 1989.

Lindemann, E.: Abteilung Peridineae (Dinoflagellatae), in: Die Natürlichen Pflanzenfamilien nebst ihren Gattungen und wichtigeren Arten insbesondere den Nutzpflanzen. Zweite stark vermehrte und verbesserte Auflage herausgegeven von A. Engler. 2 Band, edited by: Engler, A. and Prantl, K., Wilhelm Engelmann, Leipzig, Germany, 3-104, 1928.

Lippert, P. C. and Zachos, J. C.: A biogenic origin for anomalous fine-grained magnetic material at the Paleocene-Eocene boundary at Wilson Lake, New Jersey, Paleoceanography, 22, PA4104, doi:10.1029/2007PA001471, 2007.

Liu, C., Browning, J. V., Miller, K. G., and Olsson, R. K.: Paleocene benthic foraminiferal biofacies and sequence stratigraphy, Island Beach borehole, New Jersey, in: Proceedings of the Ocean Drilling Program, Scientific Results, 150X, edited by: Miller, K. G., and Snyder, S. W., Ocean Drilling Program, College Station, TX, 267-375, 1997.

Miller, K. G.: Coastal Plain Drilling And The New Jersey Sea-Level Transect, in: Proceedings of the Ocean Drilling Program, Scientific Results, Volume 150X, edited by: Miller, K. G. and Snyder, S. W., Ocean Drilling Program, College Station, TX, 3-12, 1997.

Miller, K. G., Sugarman, P. J., Browning, J. V., et al.: Proceedings of the Ocean Drilling Program, Initial Reports 174AX. doi:10.2973/odp.proc.ir.174ax.1998, Ocean Drilling Program, College Station, TX, 1998.

Nicolo, M. J., Dickens, G. R., Hollis, C. J., and Zachos, J. C.: Multiple early Eocene hyperthermals: Their sedimentary expression on the New Zealand continental margin and in the deep sea, Geology, 35, 699-702, 2007.

Pagani, M., Caldeira, K., Archer, D., and Zachos, J. C.: An Ancient Carbon Mystery, Science, 314, 1556-1557, 10.1126/science. 1136110, 2006.

Pascher, A.: Über Flagellaten und Algen, Deutsche Botanische Gesellachaft, Berichte, 32, 136-160, 1914.

Powell, A. J., Brinkhuis, H., and Bujak, J. P.: Upper Paleocene - Lower Eocene dinoflagellate cyst sequence biostratigraphy of southeast England, in: Correlation of the Early Paleogene in Northwest Europe, Geological Society Special Publication, 101, edited by: Knox, R. W. O. B., Corfield, R. M., and Dunay, R. S., 145-183, 1996.

Pross, J.: Paleo-oxygenation in Tertiary epeiric seas: Evidence from dinoflagellate cysts, Palaeogeogr. Palaeocl., 166, 369-381, 2001.

Pross, J. and Schmiedl, G.: Early Oligocene dinoflagellate cysts from the Upper Rhine Graben (SW Germany): Paleoenvironmental and paleoclimatic implications, Mar. Micropaleontol., 45, 1-24, 2002.

Pross, J. and Brinkhuis, H.: Organic-walled dinoflagellate cysts as paleoenvironmental indicators in the Paleogene; a synopsis of concepts, Paläontologische Zeitschrift, 79, 53-59, 2005.
Ravizza, G., Norris, R. N., Blusztajn, J., and Aubry, M.-P.: An osmium isotope excursion associated with the late Paleocene thermal maximum: Evidence of intensified chemical weathering, $\mathrm{Pa}-$ leoceanography, 16, 155-163, 2001.

Reichart, G.-J., Brinkhuis, H., Huiskamp, F., and Zachariasse, W. J.: Hyper-stratification following glacial overturning events in the northern Arabian Sea, Paleoceanography, 19, PA2013, doi:2010.1029/2003PA000900, 2004.

Robert, C. and Kennett, J. P.: Antarctic subtropical humid episode at the Paleocene-Eocene boundary: clay mineral evidence, Geology, 22, 211-214, 1994.

Rochon, A., Lewis, J., Ellegaard, M., and Harding, I. C.: The Gonyaulax spinifera (Dinophyceae) "complex": Perpetuating the paradox?, Rev. Palaeobot. Palyno., 155, 52-60, 2009.

Röhl, U., Brinkhuis, H., Stickley, C. E., Fuller, M., Schellenberg, S. A., Wefer, G., and Williams, G. L.: Sea level and astronomically induced environmental changes in Middle and Late Eocene sediments from the East Tasman Plateau, in: The Cenozoic Southern Ocean: Tectonics, Sedimentation, and Climate Change Between Australia and Antarctica. American Geophysical Union Geophysical Monograph Series, 151, edited by: Exon, N. F., Malone, M., and Kennett, J. P., 127-151, 2004.

Röhl, U., Westerhold, T., Bralower, T. J., and Zachos, J. C.: On the duration of the Paleocene - Eocene thermal maximum (PETM), Geochem. Geophy. Geosy., 8, Q12002, doi:10.1029/2007GC001784, 2007.

Schmitz, B., Pujalte, V., and Nunez-Betelu, K.: Climate and sealevel perturbations during the Initial Eocene Thermal Maximum: evidence from siliciclastic units in the Basque Basin (Ermua, Zumaia and Trabakua Pass), northern Spain, Palaeogeogr. Palaeocl., 165, 299-320, 2001.

Schouten, S., Woltering, M., Rijpstra, W. I. C., Sluijs, A., Brinkhuis, H., and Sinninghe Damsté, J. S.: The Paleocene-Eocene carbon isotope excursion in higher plant organic matter: Differential fractionation of angiosperms and conifers in the Arctic, Earth Planet. Sci. Lett., 258, 581-592, 2007.

Scotese, C. P. and Golanka, J.: Paleogeographic atlas, PALEOMAP progress report 20-0692, University of Texas, Arlington, 34 pp., 1992.

Sluijs, A., Brinkhuis, H., Stickley, C. E., Warnaar, J., Williams, G. L., and Fuller, M.: Dinoflagellate cysts from the Eocene/Oligocene transition in the Southern Ocean; results from ODP Leg 189., in: Proceedings Ocean Drilling Program, Scientific Results 189, edited by: Exon, N. F., Kennett, J. P., and Malone, M. J., online available at: http://www-odp.tamu.edu/ publications/189_SR/104/104.htm, College Station, Texas, 1-42, 2003.

Sluijs, A., Pross, J., and Brinkhuis, H.: From greenhouse to icehouse; organic-walled dinoflagellate cysts as paleoenvironmental indicators in the Paleogene, Earth-Sci. Rev., 68, 281-315, 2005.

Sluijs, A., Schouten, S., Pagani, M., Woltering, M., Brinkhuis, H., Sinninghe Damsté, J. S., Dickens, G. R., Huber, M., Reichart, G.-J., Stein, R., Matthiessen, J., Lourens, L. J., Pedentchouk, N., Backman, J., Moran, K., and the Expedition 302 Scientists: Subtropical Arctic Ocean temperatures during the Palaeocene/Eocene thermal maximum, Nature, 441, 610-613, 2006.

Sluijs, A., Bowen, G. J., Brinkhuis, H., Lourens, L. J., and Thomas, E.: The Palaeocene-Eocene thermal maximum super green- 
house: biotic and geochemical signatures, age models and mechanisms of global change, in: Deep time perspectives on Climate Change: Marrying the Signal from Computer Models and Biological Proxies, edited by: Williams, M., Haywood, A. M., Gregory, F. J., and Schmidt, D. N., The Micropalaeontological Society, Special Publications, The Geological Society, London, 323-347, 2007a.

Sluijs, A., Brinkhuis, H., Schouten, S., Bohaty, S. M., John, C. M., Zachos, J. C., Sinninghe Damsté, J. S., Crouch, E. M., and Dickens, G. R.: Environmental precursors to light carbon input at the Paleocene/Eocene boundary, Nature, 450, 1218-1221, $2007 \mathrm{~b}$.

Sluijs, A., Brinkhuis, H., Crouch, E. M., John, C. M., Handley, L., Munsterman, D., Bohaty, S., M., Zachos, J. C., Reichart, G.-J., Schouten, S., Pancost, R. D., Sinninghe Damsté, J. S., Welters, N. L. D., Lotter, A. F., and Dickens, G. R.: Eustatic variations during the Paleocene-Eocene greenhouse world, Paleoceanography, 23, PA4216; doi:4210.1029/2008PA001615, 2008a.

Sluijs, A., Röhl, U., Schouten, S., Brumsack, H.-J., Sangiorgi, F., Sinninghe Damsté, J. S., and Brinkhuis, H.: Arctic late Paleocene-early Eocene paleoenvironments with special emphasis on the Paleocene-Eocene thermal maximum (Lomonosov Ridge, Integrated Ocean Drilling Program Expedition 302), Paleoceanography, 23, PA1S11, doi:10.1029/2007PA001495, 2008b.

Sluijs, A., Brinkhuis, H., Williams, G. L., and Fensome, R. A.: Taxonomic revision of some Cretaceous-Cenozoic spiny organicwalled, peridinioid dinoflagellate cysts, Rev. Palaeobot. Palyno., 154, 34-53 doi:10.1016/j.revpalbo.2008.1011.1006, 2009.

Speijer, R. P. and Schmitz, B.: A benthic foraminiferal record of Paleocene sea level and trophic/redox conditions at Gebel Aweina, Egypt, Palaeogeogr. Palaeocl., 137, 79-101, 1998.

Sriver, R. L. and Huber, M.: Observational evidence for an ocean heat pump induced by tropical cyclones, Nature, 447, 577-580, 2007.

Steurbaut, E., Magioncalda, R., Dupuis, C., Van Simaeys, S., Roche, E., and Roche, M.: Palynology, paleoenvironments, and organic carbon isotope evolution in lagoonal Paleocene-Eocene boundary settings in North Belgium, in: Causes and consequences of Globally Warm Climates in the Early Paleogene, Geological Society of America Special Paper 369, edited by: Wing, S. L., Gingerich, P., Schmitz, B., and Thomas, E., Geological Society of America, Boulder, Colorado, 291-317, 2003.
Taylor, F. J. R.: On dinoflagellate evolution, BioSystems, 13, 65$108,1980$.

ter Braak, C. J. F. and Smilauer, P.: CANOCO Reference Manual and User's Guide to Canoco for Windows: Software for Canonical Community Ordination (version 4.5), Microcomputer Power, Ithaca, NY, USA, 2002.

Thomas, E. and Shackleton, N. J.: The Palaeocene-Eocene benthic foraminiferal extinction and stable isotope anomalies, in: Correlation of the Early Paleogene in Northwestern Europe, Geological Society London Special Publication, 101, edited by: Knox, R. W. O. B., Corfield, R. M., and Dunay, R. E., Geological Society of London, London, UK, 401-441, 1996.

Wall, D., Dale, B., Lohmann, G. P., and Smith, W. K.: The environmental and climatic distribution of dinoflagellate cysts in modern marine sediments from regions in the North and South Atlantic Oceans and adjacent seas, Mar. Micropaleontol., 2, 121200, 1977.

Wing, S. L., Harrington, G. J., Smith, F. A., Bloch, J. I., Boyer, D. M., and Freeman, K. H.: Transient Floral Change and Rapid Global Warming at the Paleocene-Eocene Boundary, Science, 310, 993-996, doi:10.1126/science.1116913, 2005.

Zachos, J. C., Wara, M. W., Bohaty, S., Delaney, M. L., Petrizzo, M. R., Brill, A., Bralower, T. J., and Premoli Silva, I.: A transient rise in tropical sea surface temperature during the PaleoceneEocene thermal maximum, Science, 302, 1551-1554, 2003.

Zachos, J. C., Röhl, U., Schellenberg, S. A., Sluijs, A., Hodell, D. A., Kelly, D. C., Thomas, E., Nicolo, M., Raffi, I., Lourens, L. J., McCarren, H., and Kroon, D.: Rapid Acidification of the Ocean during the Paleocene-Eocene Thermal Maximum, Science, 308, 1611-1615, 2005.

Zachos, J. C., Schouten, S., Bohaty, S., Quattlebaum, T., Sluijs, A., Brinkhuis, H., Gibbs, S., and Bralower, T. J.: Extreme warming of mid-latitude coastal ocean during the Paleocene-Eocene Thermal Maximum: Inferences from $\mathrm{TEX}_{86}$ and Isotope Data, Geology, 34, 737-740, 2006. 